\title{
First Directly Retrieved Global Distribution of Tropospheric Column Ozone from GOME: Comparison with the GEOS-CHEM Model
}

\section{Citation}

Liu, Xiong, Kelly Chance, Christopher E. Sioris, Thomas P. Kurosu, Robert J.D. Spurr, Randall V. Martin, Tzung-May Fu, et al. 2006. First directly-retrieved global distribution of tropospheric column ozone from GOME: Comparison with the GEOS-CHEM model. Journal of Geophysical Research 111: D02308.

\section{Published Version}

doi:10.1029/2005JD006564

\section{Permanent link}

http://nrs.harvard.edu/urn-3:HUL.InstRepos:3743791

\section{Terms of Use}

This article was downloaded from Harvard University's DASH repository, and is made available under the terms and conditions applicable to Other Posted Material, as set forth at http:// nrs.harvard.edu/urn-3:HUL.InstRepos:dash.current.terms-of-use\#LAA

\section{Share Your Story}

The Harvard community has made this article openly available.

Please share how this access benefits you. Submit a story.

Accessibility 


\title{
First directly retrieved global distribution of tropospheric column ozone from GOME: Comparison with the GEOS-CHEM model
}

\author{
Xiong Liu, ${ }^{1}$ Kelly Chance, ${ }^{1}$ Christopher E. Sioris, ${ }^{1}$ Thomas P. Kurosu, ${ }^{1}$ \\ Robert J. D. Spurr, ${ }^{1,2}$ Randall V. Martin, ${ }^{1,3}$ Tzung-May Fu, ${ }^{4}$ Jennifer A. Logan, ${ }^{4}$ \\ Daniel J. Jacob, ${ }^{4}$ Paul I. Palmer, ${ }^{4,5}$ Michael J. Newchurch, ${ }^{6}$ Inna A. Megretskaia, ${ }^{4}$ \\ and Robert B. Chatfield ${ }^{7}$
}

Received 4 August 2005; revised 16 October 2005; accepted 17 November 2005; published 28 January 2006.

[1] We present the first directly retrieved global distribution of tropospheric column ozone from Global Ozone Monitoring Experiment (GOME) ultraviolet measurements during December 1996 to November 1997. The retrievals clearly show signals due to convection, biomass burning, stratospheric influence, pollution, and transport. They are capable of capturing the spatiotemporal evolution of tropospheric column ozone in response to regional or short time-scale events such as the 1997-1998 El Niño event and a 10-20 DU change within a few days. The global distribution of tropospheric column ozone displays the well-known wave- 1 pattern in the tropics, nearly zonal bands of enhanced tropospheric column ozone of $36-48 \mathrm{DU}$ at $20^{\circ} \mathrm{S}-30^{\circ} \mathrm{S}$ during the austral spring and at $25^{\circ} \mathrm{N}-45^{\circ} \mathrm{N}$ during the boreal spring and summer, low tropospheric column ozone of $<30$ DU uniformly distributed south of $35^{\circ} \mathrm{S}$ during all seasons, and relatively high tropospheric column ozone of $>33$ DU at some northern high-latitudes during the spring. Simulation from a chemical transport model corroborates most of the above structures, with small biases of $< \pm 5$ DU and consistent seasonal cycles in most regions, especially in the southern hemisphere. However, significant positive biases of 5-20 DU occur in some northern tropical and subtropical regions such as the Middle East during summer. Comparison of GOME with monthly-averaged Measurement of Ozone and Water Vapor by Airbus in-service Aircraft (MOZAIC) tropospheric column ozone for these regions usually shows good consistency within $1 \sigma$ standard deviations and retrieval uncertainties. Some biases can be accounted for by inadequate sensitivity to lower tropospheric ozone, the different spatiotemporal sampling and the spatiotemporal variations in tropospheric column ozone.

Citation: Liu, X., et al. (2006), First directly retrieved global distribution of tropospheric column ozone from GOME: Comparison with the GEOS-CHEM model, J. Geophys. Res., 111, D02308, doi:10.1029/2005JD006564.

\section{Introduction}

[2] Since Fishman and Larsen [1987] made their pioneering study to derive Tropospheric Column Ozone (TCO) using the tropospheric ozone residual method, various techniques have been developed to derive TCO

\footnotetext{
${ }^{1}$ Atomic and Molecular Physics Division, Harvard-Smithsonian Center for Astrophysics, Cambridge, Massachusetts, USA.

${ }^{2}$ RT Solutions, Inc., Cambridge, Massachusetts, USA.

${ }^{3}$ Department of Physics and Atmospheric Sciences, Dalhousie University, Halifax, Nova Scotia, Canada.

${ }^{4}$ Division of Engineering and Applied Sciences, Harvard University, Cambridge, Massachusetts, USA. UK.

${ }^{5}$ Now at School of Earth and Environment, University of Leeds, Leeds,

${ }^{6}$ Atmospheric Science Department, University of Alabama in Huntsville, Huntsville, Alabama, USA.

${ }^{7}$ Atmospheric Chemistry and Dynamics Branch, NASA Ames Research Center, Moffett Field, California, USA.
}

Copyright 2006 by the American Geophysical Union. 0148-0227/06/2005JD006564\$09.00 from satellite measurements [Fishman et al., 1990, 2003; Jiang and Yung, 1996; Kim et al., 1996, 2001; Kim and Newchurch, 1996; Hudson and Thompson, 1998; Ziemke et al., 1998, 2001; Newchurch et al., 2001, 2003a; Chandra et al., 2003; Valks et al., 2003]. Most of the methods are residual-based, so that TCO is derived as the difference between Total column Ozone (TO) (mostly from Total Ozone Monitoring Spectrometer, i.e., TOMS) and Stratospheric Column Ozone (SCO) from other satellite measurements or determined from TOMS data. The exception is the scan-angle method by Kim et al. [2001], which utilizes the dependence of ozone detection on the scan angle geometry to derive TCO from TOMS data. In all these methods, assumptions are often made about the distribution and variability of SCO. Because of the usually poor spatiotemporal resolution of coincident or derived SCO data and the large spatiotemporal variability in SCO at higher latitudes, most of the reliable TCO products from these methods are climatological (i.e., monthly means) and limited to the tropics. Although the derived TCO from various methods agrees reasonably well with ozonesonde 
observations at selected ozonesonde stations and shows similar overall structures (e.g., the wave-1 pattern in the tropics), significant differences exist among the methods. Sun [2003] evaluated six methods applied to TOMS TO data and found that the derived TCO in the tropics displays root-mean-square differences of $4-12$ DU (1 DU $=2.69 \times$ $10^{16}$ molecules $\mathrm{cm}^{-2}$ ) over the Pacific and 6-18 DU over the Atlantic.

[3] The Global Ozone Monitoring Experiment (GOME) was launched in 1995 on the European Space Agency's (ESA's) second Earth Remote Sensing (ERS-2) satellite to measure backscattered radiance spectra from the Earth's atmosphere in the wavelength range 240-790 nm [ESA, 1995]. Observations with moderate spectral resolution of $0.2-0.4 \mathrm{~nm}$ and high signal to noise ratio in the ultraviolet ozone absorption bands make it possible to retrieve the vertical distribution of ozone down through the troposphere [Chance et al., 1997]. The advantage of direct retrievals over the residual-based approaches is that daily global distributions of tropospheric ozone can be derived without other collocated satellite measurements of SCO, or the need to make assumptions about the spatiotemporal distribution of SCO. In recent years, several algorithms have been developed to directly retrieve ozone profiles, including tropospheric ozone, from GOME data [Munro et al., 1998; Hoogen et al., 1999; Hasekamp and Landgraf, 2001; van $\operatorname{der} A$ et al., 2002]. All these methods show that limited tropospheric ozone information can be directly retrieved from GOME measurements. However, global distributions of TCO from these algorithms have not so far been published.

[4] We have developed an ozone profile and tropospheric ozone retrieval algorithm for GOME data [Liu et al., 2005]. TCO is directly retrieved with the known tropopause used to divide the stratosphere and troposphere. The retrieved TCO has been extensively validated against ozonesonde TCO on a daily basis at 33 stations from $75^{\circ} \mathrm{N}$ to $71^{\circ} \mathrm{S}$ during $1996-1999$. The retrievals capture most of the temporal variability in ozonesonde TCO; the mean biases are mostly within 3 DU (15\%) and the $1 \sigma$ standard deviations are within 3-8 DU (13-27\%) [Liu et al., 2005].

[5] The purpose of this paper is to present the first directly retrieved global distribution of TCO from GOME as described in Liu et al. [2005]. To evaluate the global features of TCO seen from GOME, we compare our retrievals with results from a totally different approach simulation with the GEOS-CHEM chemical transport model [Bey et al., 2001b]. Section 2 briefly reviews GOME retrievals, discusses tropopause issues, and describes the approach of mapping irregular data (e.g., GOME retrievals) onto regular grids. Section 3 gives a brief description of the GEOS-CHEM model and the sampling of GEOS-CHEM data for comparison. In section 4 , we demonstrate the capability of GOME retrievals to capture TCO changes on regional scales and on a daily basis. Section 5 presents the global distribution of TCO during December 1996November 1997 (this time period is abbreviated as "DN97"). We compare GOME and GEOS-CHEM TCO in section 6. In section 7, we evaluate both GOME and GEOS-CHEM TCO with Measurement of Ozone and Water Vapor by Airbus in-service Aircraft (MOZAIC) measurements, focusing on regions with significant GOME/GEOS-CHEM (GM/GC) discrepancies.

\section{GOME Retrievals, Tropopause, and Spatial Mapping}

[6] In our algorithm, profiles of partial column ozone are retrieved from GOME ultraviolet spectra (289-307 and 326-339 nm) using the optimal estimation method [Rodgers, 2000]. The tropospheric ozone information comes mainly from the temperature-dependent Huggins absorption bands (e.g., 326-339 nm). With extensive radiometric and wavelength calibrations and improvements of forward modeling and forward model inputs, we are able to reduce the fitting residuals to $<0.2 \%$ in the Huggins bands. The retrieved profiles have 11 layers with the daily National Centers for Environmental Prediction (NCEP) tropopause as one of the levels; each layer is $\sim 5 \mathrm{~km}$ thick except for the top layer $(\sim 10 \mathrm{~km})$. The troposphere is divided into two or three equal log-pressure layers depending on the location of the tropopause; the TCO is the sum of these tropospheric partial columns. We use the latitudinaland monthly- dependent version-8 TOMS climatology [McPeters et al., 2003] and its standard deviations to initialize and regularize the retrievals. Thus the used a priori information is not related to the GEOS-CHEM model simulations. The a priori influence of the retrieved TCO ranges from $\sim 15 \%$ in the tropics to $\sim 50 \%$ at high latitudes. The retrieval precision in TCO is usually $<6 \%$ (1.5 DU) in the tropics and $<12 \%$ ( $3 \mathrm{DU}$ ) at high latitudes. Due to the limited vertical resolutions of the retrievals, the retrieved profile and TCO are estimates of the actual ones smoothed by the Averaging Kernels (AKs). The effect of stratospheric ozone on the retrieved TCO is characterized as part of the smoothing error. This smoothing error in the TCO ranges from $\sim 12 \%$ (3 DU) in the tropics to $\sim 25 \%$ (6 DU) at high latitudes. The globally-averaged retrieval accuracy (precision, smoothing, and other errors) is estimated to be $21 \%$. The spatial resolution of the GOME retrievals is normally $960 \times 80 \mathrm{~km}^{2}$. Due to the orbital inclination, the north-south distance of a retrieved pixel is $\sim 3^{\circ}$ in latitude. Clouds are treated as Lambertian surfaces and partial clouds are modeled with the independent pixel approximation. Ozone amounts below clouds are handled through ozone weighting functions and smoothing. For full cloudy conditions, the ozone below clouds is iteratively updated only through smoothing from above clouds since the weighting functions are zero; for partial clouds, it is updated through both clear-sky weighting functions multiplied by cloud fraction and smoothing. For further details on the algorithm including retrieval characterization and error analysis see Liu et al. [2005].

[7] The GOME ozone profile and TCO retrieval is distinctly different from the Solar Backscatter Ultraviolet (SBUV) ozone profile retrieval [Bhartia et al., 1996] and the TCO derivation using TOMS TO and SBUV ozone profiles [Fishman et al., 2003]. Although ozone profiles are derived at similar vertical altitude grids, SBUV retrievals are derived from 12 discrete wavelengths from $255 \mathrm{~nm}$ to $339 \mathrm{~nm}$ and do not contain the tropospheric ozone information in the Huggins ozone absorption bands other than the total ozone information. Therefore, SBUV ozone profiles below $\sim 25 \mathrm{~km}$ are heavily affected by the a priori 
climatology despite the column ozone below $\sim 25 \mathrm{~km}$ is relatively free of a priori influence [Bhartia et al., 1996]. Because of the severer a priori influence below $25 \mathrm{~km}$ than GOME retrievals, TCO cannot be directly derived from the SBUV ozone profiles like from GOME. In the TOMS/ SBUV residual approach to derive TCO, SBUV ozone profiles are empirically corrected to derive SCO [Fishman et al., 2003], which essentially assumes the column ozone below $\sim 20 \mathrm{~km}$ is correct and redistributes the ozone in the 3 layers below $\sim 20 \mathrm{~km}$ using profile shapes from a global tropospheric ozone climatology [Logan, 1999]. In addition, SCO is derived over a five-day period due to the relatively less SBUV data sampling compared to TOMS. While in our retrieval, SCO and TCO are derived from each profile without additional correction and collocation.

[8] Precise knowledge of the tropopause height is critical for deriving TCO, especially in regions with large vertical ozone gradient near the tropopause. The NCEP tropopause used in the original algorithm may not be truly representative of the real boundary between stratospheric and tropospheric air, especially in the extratropics. Using this tropopause may result in the inclusion of stratospheric air, which contains high concentrations of ozone, in the troposphere. A better approximation is the dynamic tropopause, which is based on isentropic Potential Vorticity (PV) [Hoerling et al., 1991; Hoinka, 1998]. However, the concept of dynamic tropopause fails to work in the tropics [Hoinka, 1998]. To obtain the tropopause globally, it is defined as the maximum pressure (minimum altitude) of the dynamic and thermal tropopauses, following the suggestion of Hoerling et al. [1991]. The final tropopause near the equator is completely based on the NCEP tropopause, and at higher latitudes it is mostly based on the dynamic tropopause. We determine the dynamic tropopause from European Centre for Medium-Range Weather Forecasts (ECMWF) reanalysis fields of PV profiles (12PM, daily) with a PV value of 2.5 PVU (potential vorticity unit, 1 PVU = $\left.1.0 \times 10^{-6} \mathrm{~K} \mathrm{~m}^{2} \mathrm{~kg}^{-1} \mathrm{~s}^{-1}\right)$ to delineate the tropopause (L. Pfister, personal communication, 2005). This combined tropopause is usually at pressure higher (lower in altitude) by $15-45 \mathrm{hPa}$ in the extratropics compared to the NCEP tropopause. To obtain the TCO for the new tropopause, we perform interpolation from the cumulative ozone profiles.

[9] Figure 1 shows the monthly and zonally mean tropopause pressure in DN97 as derived above. In the tropics $\left(\sim 20^{\circ} \mathrm{N}-20^{\circ} \mathrm{S}\right)$, the tropopause pressure is within $90-130 \mathrm{hPa}$ and does not change much with time. It usually increases with increasing latitude to $270-370 \mathrm{hPa}$. At mid-latitudes $\left(30^{\circ} \mathrm{N}-60^{\circ} \mathrm{N}, 30^{\circ} \mathrm{S}-50^{\circ} \mathrm{S}\right)$, the tropopause pressure shows strong seasonal variation, largest in winter and early spring and smallest in summer and early fall in both hemispheres. The seasonal variations at high latitudes become out of phase with those at mid-latitudes.

[10] GOME retrievals, tropopause data, and GEOSCHEM simulations are mapped onto a common, regular grid using an area-weighted tessellation method by R. J. D. Spurr (Area-weighting tesselation for nadir-viewing spectrometers, submitted to International Journal of Remote Sensing, 2004). Monthly mean values of GOME TCO

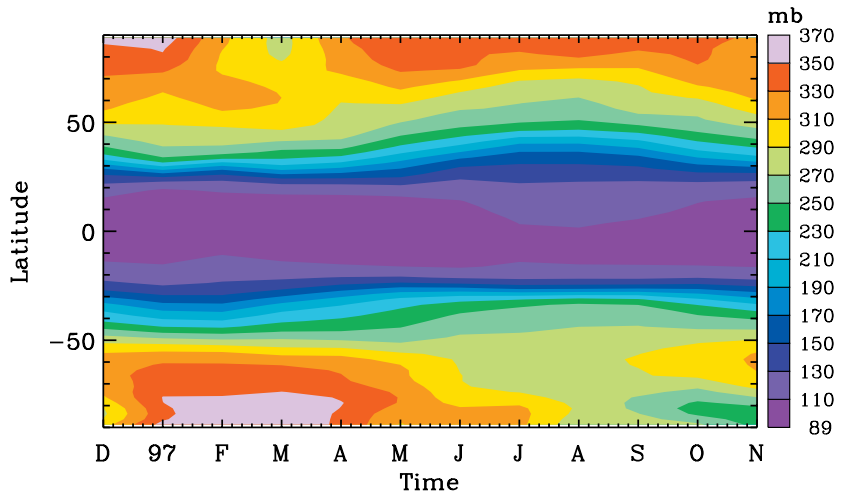

Figure 1. Monthly and zonal mean tropopause pressure from December 1996 to November 1997, combined from ECMWF dynamic and NCEP tropopause pressures.

are computed for each grid cell as the average of all area-weighted contributions of GOME pixels that fall into the grid cell.

\section{GEOS-CHEM Model and Its Sampling}

[11] We use the GEOS-CHEM chemical transport model to simulate global tropospheric chemistry (version 6.1.3; http://www-as.harvard.edu/chemistry/trop/geos/). The model is driven by assimilated meteorology [Bey et al., 2001b] from the Goddard Earth Observing System (GEOS-STRAT) of the NASA Global Modeling Assimilation Office. The GEOS-STRAT meteorological data set is updated every three hours for surface variables and every six hours for other variables with a resolution of $1^{\circ} \times 1^{\circ}$ horizontally and 46 sigma levels vertically up to $0.1 \mathrm{hPa}$. For driving GEOS-CHEM simulations, we regrid the horizontal resolution to $2^{\circ}$ latitude $\times 2.5^{\circ}$ longitude and merge the stratospheric levels to yield a total of 26 vertical levels. An 18-month simulation was conducted for the June 1996 through November 1997 period. The first 6 months are used for initialization and the last 12 months are used for comparison to GOME observations.

[12] The GEOS-CHEM ozone simulation is as described by Bey et al. [2001b] with 1997 anthropogenic emission estimates [Martin et al., 2002b], seasonal average biomass burning emission from ATSR and AVHRR fire-counts [Duncan et al., 2003], and minor updates to natural emissions and interactions with aerosols [Martin et al., 2002b, 2003; Park et al., 2004]. An additional minor update for this study is the use of 1997-specific leaf area index (LAI) data derived from the AVHRR satellite instrument [Myneni et al., 1997] to better represent biogenic emissions and deposition. The model uses the Synoz flux boundary condition [McLinden et al., 2000] to impose a downward ozone flux of $475 \mathrm{Tg} \mathrm{O}_{3} \mathrm{yr}^{-1}$ from the stratosphere. The GEOS-CHEM simulation of ozone has been evaluated extensively in previous papers with observations from ozonesondes [Bey et al., 2001b; Li et al., 2002b, 2004; Liu et al., 2002], surface sites [Fiore et al., 2002, 2003a, 2003b; Li et al., 2002a; Goldstein et al., 2004], aircraft [Bey et al., 2001a; Jaeglé et al., 2003; Bertschi et al., 2004; Hudman et al., 2004], and TOMS tropospheric ozone residuals [Chandra et al., 2002, 2003; Martin et al., 2002a]. 

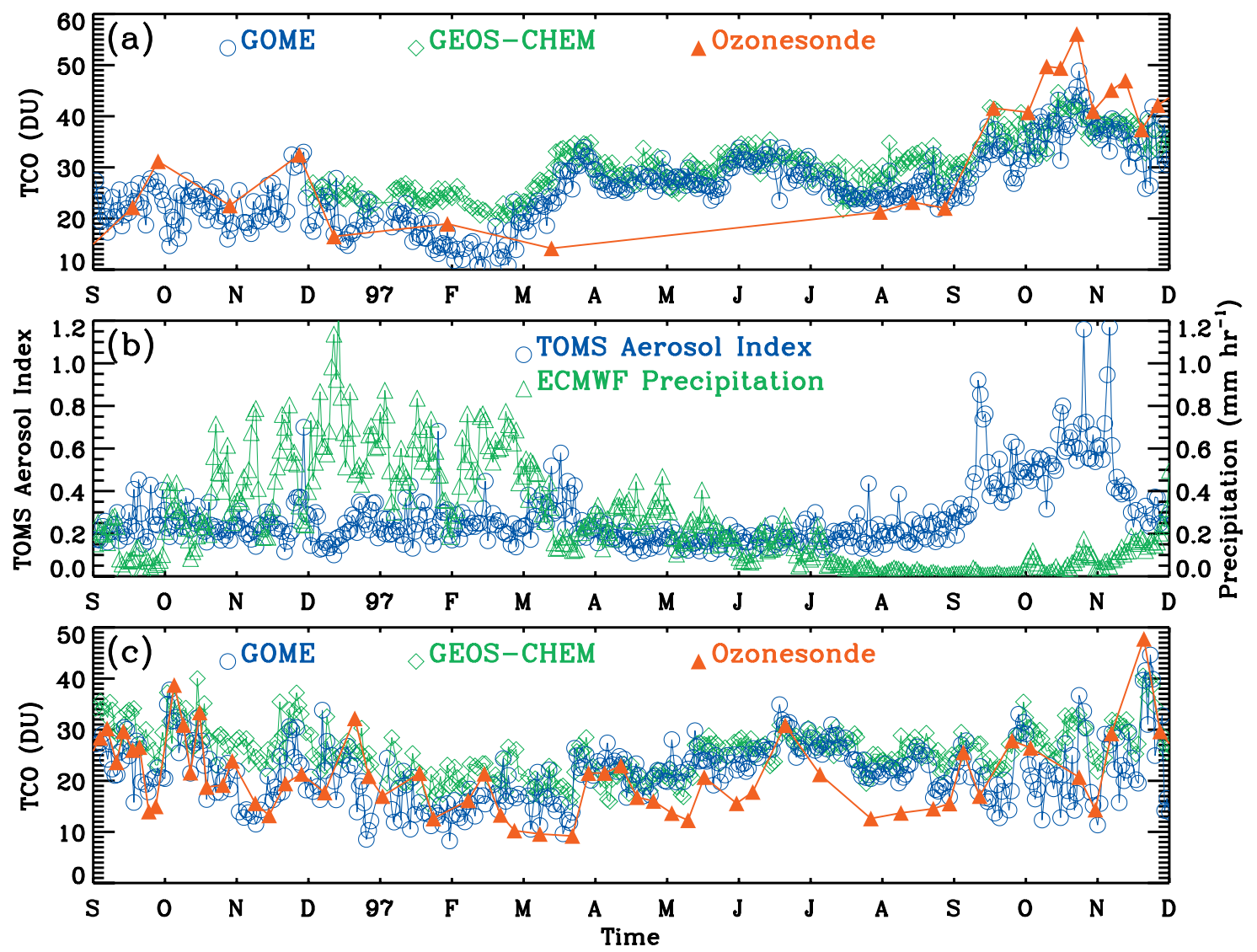

Figure 2. (a) Time series of GOME and GEOS-CHEM tropospheric column ozone (TCO) from 09/ 1996 to $11 / 1997$ averaged over Indonesia $\left(110^{\circ} \mathrm{E}-125^{\circ} \mathrm{E}, 6.6^{\circ}-8.6^{\circ} \mathrm{S}\right)$ and ozonesonde TCO measured at Java $\left(7.6^{\circ} \mathrm{S}, 112.7^{\circ} \mathrm{E}\right.$ ). (b) Same as Figure 2a, but for TOMS aerosol index and ECMWF total precipitation. (c) Same as Figure 2a, but over the tropical southern Pacific $\left(13.2^{\circ} \mathrm{S}-15.2^{\circ} \mathrm{S}, 180^{\circ} \mathrm{W}-\right.$ $\left.158^{\circ} \mathrm{W}\right)$ and at American Samoa $\left(14.2^{\circ} \mathrm{S}, 170^{\circ} \mathrm{W}\right)$.

[13] To account for the different spatial and vertical resolutions of GOME retrievals and GEOS-CHEM simulations, we sample the GEOS-CHEM data for each GOME pixel, apply GOME AKs to degrade GEOS-CHEM profiles to the vertical resolution of GOME retrievals, and finally obtain the corresponding TCO by integrating the transformed profiles to the same tropopause used to obtain GOME TCO. The sampled GEOS-CHEM data are then similarly mapped onto regular grids. The adjustments to the GEOS-CHEM TCO are usually $(98 \%)<4$ DU between $50^{\circ} \mathrm{N}-50^{\circ} \mathrm{S}$. Larger positive biases occur at higher latitudes (e.g., mean adjustment north of $50^{\circ} \mathrm{N}$ is $+2.5 \mathrm{DU}$ ), where the GEOS-CHEM TCO is relatively small and the ozone vertical gradient near the tropopause is large.

\section{Examples of Daily Tropospheric Column Ozone}

[14] To demonstrate the capability of our retrievals to capture short-term variations in TCO, we show the time series of retrieved GOME TCO in Figure 2 at two locations during September 1996-November 1997. The effects of the 1997-1998 El Niño events on tropospheric ozone have been closely examined by studies using in situ, satellite observations, or chemistry and transport models [Chandra et al., 1998, 2002; Hauglustaine et al., 1999; Fujiwara et al., 2000; Sudo and Takahashi, 2001; Thompson et al., 2001]. This well-studied event provides a good case to examine the retrieved TCO. Figure 2a shows the GOME and GEOS-CHEM TCO averaged over Indonesia $\left(6.6^{\circ} \mathrm{S}-\right.$ $\left.8.6^{\circ} \mathrm{S}, 100^{\circ} \mathrm{E}-125^{\circ} \mathrm{E}\right)$ as well as available ozonesonde $\mathrm{TCO}$ at Java $\left(7.6^{\circ} \mathrm{S}, 112.7^{\circ} \mathrm{E}\right)$ [Fujiwara et al., 2000]. The average over a $25^{\circ}$ longitude range is used to obtain the TCO daily coverage. Figure $2 \mathrm{~b}$ shows the TOMS Aerosol Index (AI) [Hsu et al., 1996] and ECMWF precipitation data, which are used as proxies for biomass burning and convection, respectively. Generally, GOME TCO agrees very well with ozonesonde and GEOS-CHEM TCO (correlation coefficient $r=0.88$ with both). There is a positive correlation with the $\mathrm{AI}(r=0.48)$ and a negative correlation with the precipitation $(r=-0.58)$.

[15] The time series of GOME TCO shows detailed responses to the biomass burning and precipitation. A sudden increase of $\sim 10$ DU in late November 1996 is consistent with ozonesonde measurements, and corresponds to an increase in AI and a simultaneous decrease in the precipitation. The increasing precipitation and decreasing AI a few days afterward is reflected in a GOME TCO decrease of $\sim 12$ DU. With strong precipitation and less biomass burning from December 1996 to the middle of February 1997, the TCO remains small (10-22 DU), hitting its minimum in middle February. When the 1997-1998 El 
(a) $02 / 24-26 / 1997$

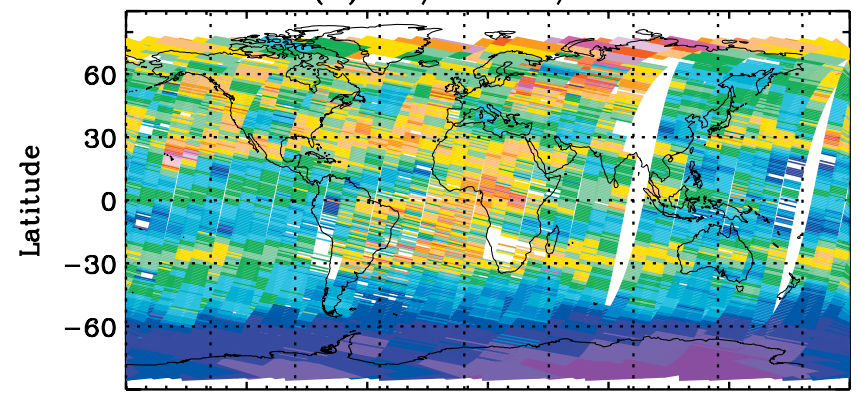

(c) $09 / 01-03 / 1997$
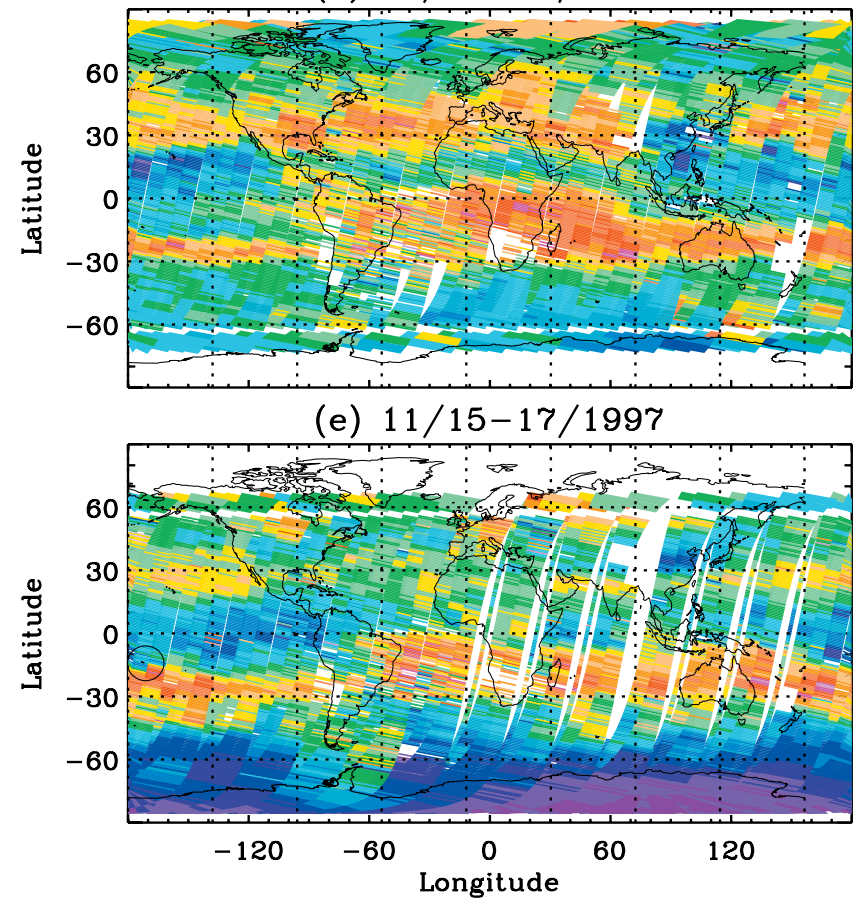

(b) $06 / 06-08 / 1997$

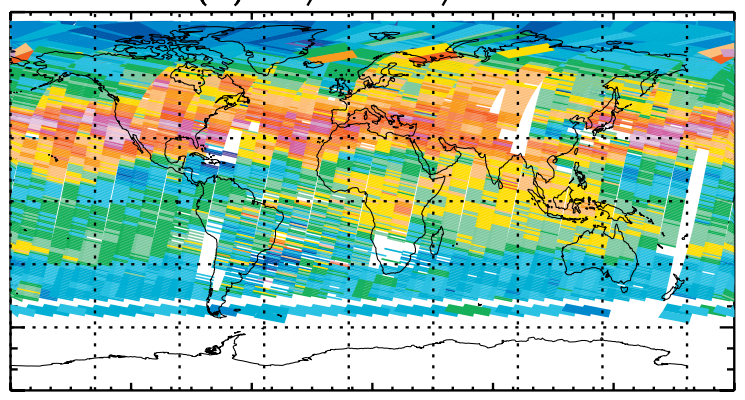

(d) $09 / 16-18 / 1997$

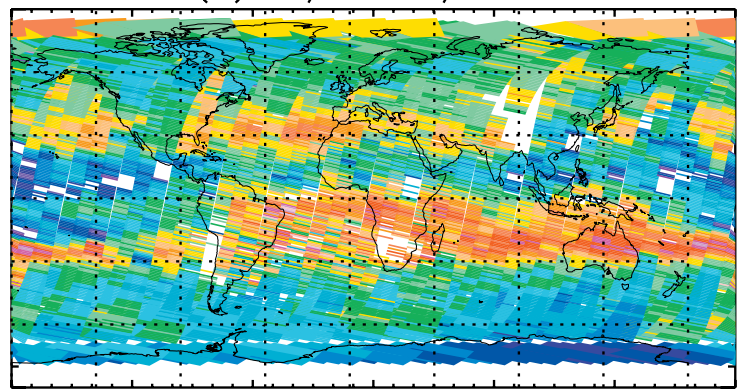

(f) $11 / 19-21 / 1997$

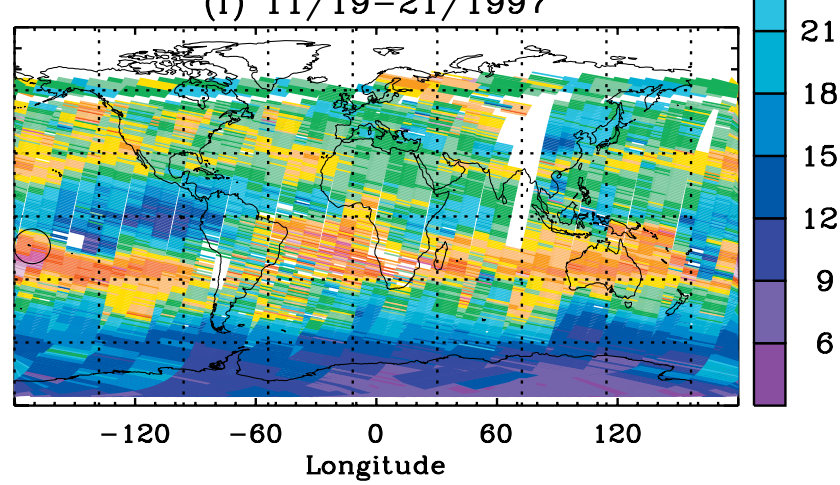

DU

Figure 3. Three-day composite global maps of GOME tropospheric column ozone. Each pixel is plotted on its actual footprint. Circles in Figures 3e and 3f encompass American Samoa.

Niño episode began to develop in early March [Chandra et al., 1998; Thompson et al., 2001], the shift of convection pattern from the western Pacific to the eastern Pacific decreases precipitation and increases AI for $\sim 10$ days. Correspondingly, GOME TCO steadily increases from $\sim 10$ DU to 34 DU. During April to late July 1997, when the weather becomes dry with low precipitation and small AI, GOME TCO (26-32 DU) agrees very well with GEOSCHEM. With the start of biomass burning over Indonesia in August 1997, the AI gradually increases, while GOME TCO first gradually increases by $\sim 5$ DU and then decreases by $\sim 6 \mathrm{DU}$. This decoupling between aerosols and ozone in late August 1997 was also observed by Thompson et al. [2001] who attributed it to transport of ozone and aerosols at different layers. During the intense biomass burning period from early September 1997 through October 1997, the variation of GOME TCO closely anti-correlates with the $\mathrm{AI}$ and is consistent with ozonesonde and GEOS-CHEM data. During October and November 1997, both GOME and GEOS-CHEM TCO are usually $\sim 5-10$ DU smaller than ozonesonde TCO. This may be due to the large spatial scale of GOME retrievals or to the reduced sensitivity of GOME retrievals to enhanced ozone near the surface. The close relationship between GEOS-CHEM and the GOME observations implies a dynamical effect, since the biomass burning in GEOS-CHEM only changes on a monthly timescale.

[16] Figure 2c shows the daily variation in TCO over the eastern Pacific centered at ozonesonde station American Samoa [Thompson et al., 2003]. GOME TCO shows good agreement with ozonesonde TCO $(r=0.78)$ and GEOSCHEM TCO $(r=0.63)$. It reproduces well the large variations (10-25 DU) in TCO over a period of $1-2$ weeks that are observed in ozonesonde data (e.g., October 1996, middle March 1997, November 1997) [Thompson et al., 2003]. The time series of GOME TCO further shows that TCO changes of 10-20 DU or by a factor of two actually occur within one or two days. The significant variability seen at this tropical remote site is consistent with the findings from Southern Hemisphere Additional Ozonesondes (SHADOZ) observations by Thompson et al. [2003].

[17] Figure 3 shows examples of three-day composite global maps of TCO (GOME achieves global coverage in three days). The noisy pattern with high and low values over 
the South Atlantic and South America is due to spurious spikes in the radiance spectra generated by the South Atlantic Anomaly. These daily maps display the wellknown zonal wave-1 pattern in the tropics, usually with high TCO over the Atlantic and Africa and low TCO over the Pacific except in Figure 3b. The elevated TCO of $\sim 30$ DU over Indonesia during April-July seen in Figure 2a extends into the India Ocean and South India (Figure 3b). An interesting feature on 24-26 February 1997 (Figure $3 \mathrm{a}$ ) is the enhanced TCO of $>40$ DU over Northern Africa. There are also high TCO values of 36-42 DU over the South Atlantic and South America. Most other retrievals except for the scan-angle method [Kim et al., 2005] see less ozone over Northern Africa during its biomass burning season (i.e., December-February) than over the South Atlantic. This "tropical Atlantic paradox" [Thompson et al., 2000] will be further discussed in sections 5-7.

[18] On 6-8 June 1997 (Figure 3b), enhanced TCO $(40-60 \mathrm{DU})$ occurs at $25^{\circ}-45^{\circ} \mathrm{N}$ throughout the globe except over the Himalayas. Both Figures $3 \mathrm{c}$ and $3 \mathrm{~d}$ show a trapezoidal TCO plume of 36-48 DU over South America, the South Atlantic, Southern Africa, and all longitudes between $20^{\circ} \mathrm{S}$ and $30^{\circ} \mathrm{S}$. Figure $3 \mathrm{~d}$ also shows a TCO increase of $\sim 12$ DU over Indonesia relative to Figure $3 \mathrm{c}$ resulting from the intense biomass burning during 3-16 September 1997 (Figure 2b). Figures 3c and $3 \mathrm{~d}$ show distinct differences at northern mid-latitudes within this half-month period. On 1-3 September 1997, high TCO values of 39-45 DU occur over the Southeastern US, over the region of US outflow to the North Atlantic, over the Middle East, and over the region of East Asia outflow to the North Pacific. On 16-18 September 1997, such high TCO values only occur over the North Atlantic. Changes of 10-20 DU occur over the United States and the Pacific (near Japan). Figures $3 \mathrm{f}$ shows that there is a plume of high TCO ( 40 DU) extending from the southern subtropics to America Samoa on 1921 November 1997. The TCO over America Samoa is 20 DU higher than that on 15-17 November 1997 (circles in Figures 3e and 3f), which is corroborated by both ozonesonde observations and GEOS-CHEM simulations (Figure 2c). The retrieved profiles (not shown) indicate that the TCO changes occur throughout the troposphere, with enhancements of 7.7, 9.7, and 5.0 DU for the three tropospheric layers $(1000-500 \mathrm{hPa}, 500-250 \mathrm{hPa}$, and 250-125 $\mathrm{hPa}$ ), suggesting that the large increase of $\sim 20$ DU near American Samoa is due to advection of subtropical high ozone air into the tropics.

\section{Climatological Distribution of Tropospheric Column Ozone}

[19] Figure 4 shows the monthly mean GOME TCO during DN97. Individual retrievals are mapped onto $2.5^{\circ} \times 2^{\circ}$ grids, consistent with the horizontal resolution of the GEOS-CHEM simulations. We exclude retrievals with cloud fractions $>0.8$ and fitting residuals $>0.6 \%$. Using a smaller threshold of cloud fraction (e.g., 0.4) does not significantly affect the monthly mean results presented below because the differences between results from cloud fractions 0.8 and 0.4 are mostly $(97 \%)$ within 3 DU. No data are taken during the daily data down-link of the on-board tape recorder to ground stations, hence the persistent blank areas (also in Figure 3) over North India and west of the Himalayas. Other blank areas, like at the polar regions, are due to data dropouts or cloud filtering. Noises due to the South Atlantic Anomaly seen in daily maps cancel out in the monthly means.

[20] The monthly mean distributions display many of the features that have been observed in earlier studies of TCO in the tropics [Fishman et al., 1990, 2003; Thompson and Hudson, 1999; Ziemke and Chandra, 1999; Kim et al., 2001; Chandra et al., 2002, 2003; Newchurch et al., 2003a; Valks et al., 2003], including the general wave-1 pattern (except in April and May 1997) with a preference in the southern hemisphere, the enhanced TCO over the Indian Ocean and Indonesia during March-June 1997, and the enhancement of 10-20 DU over Indonesia during September-November 1997. The seasonal cycle of TCO over the South Atlantic, Southern Africa and South America are also similar, with high TCO values (36-45 DU) during September-October and low TCO values (24-27 DU) during April-May. This seasonality over the tropical South Atlantic is driven by biomass burning, upper tropospheric ozone production from lightning NOx, and persistent subsidence as part of the Walker circulation [Moxim and Levy, 2000; Martin et al., 2002a]. Over the tropical North Atlantic and Northern Africa, there is no clear seasonal cycle especially north of $\sim 8^{\circ} \mathrm{N}$. The example of high TCO values ( $\left.>40 \mathrm{DU}\right)$ over Northern Africa in Figure 2a is not present in the monthly mean TCO during December 1996-February 1997 (DJF) despite the moderately enhanced TCO values of 3339 DU in DJF and in June-August 1997 (JJA) near the Gulf of Guinea. The lack of apparent seasonality over Northern Africa is similar to that shown by Valks et al. [2003], but different from that in other abovementioned studies, which usually show a minimum in DJF (i.e., showing the "tropospheric Atlantic Paradox") and a maximum in JJA or SON with a maximum/minimum difference of $\sim 15$ DU. In contrast, the derived TCO from the scanangle method is highest (44-60 DU) in DJF and lowest in JJA (28-36 DU) and does not show actual paradox [Kim et al., 2005].

[21] The TCO over the tropical Pacific displays considerable spatiotemporal variation in addition to the TCO enhancement over the western Pacific and Indonesia during April-November. The location of minimum TCO usually migrates with the motion of the Inter-tropical Converge Zone (ITCZ), which indicates the influence of convection [Kley et al., 1996]. During January-February, low TCO values of 18-24 DU extend from the central Pacific to Southern Africa $\left(5^{\circ} \mathrm{S}-20^{\circ} \mathrm{S}\right)$. There are also low TCO values over the Northwestern Pacific. This feature of two separated regions of low TCO over the Western Pacific during this period is also present in 1999 but not in 1996 and 1998. In October, there are low TCO values of 1521 DU over the Eastern Pacific; these values are 3-9 DU smaller than those in October 1996 (the largest change occurs over the Southeastern Pacific) and are caused by the shift of convection from the Western Pacific to the Central and Eastern Pacific [Chandra et al., 1998]. Figure 5a shows the monthly variation of TCO at several locations over the Pacific. The seasonal cycles differ significantly for these regions, and are generally very different from 

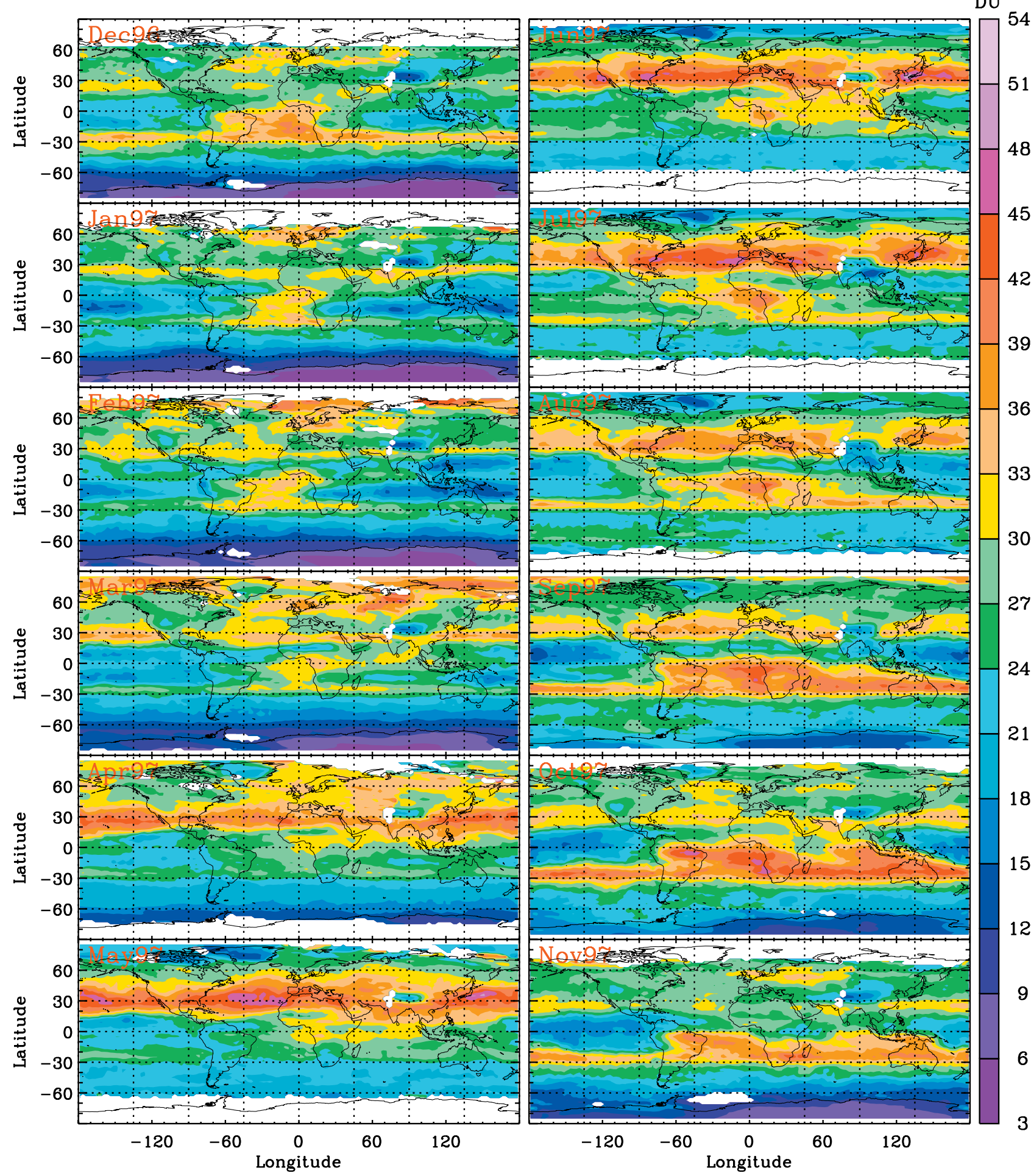

Figure 4. Global maps of GOME monthly mean tropospheric column ozone from December 1996 to November 1997.

those in the a priori climatology (Figure 5b), demonstrating that they arise from information in the measurements.

[22] The TCO at the dateline is an important input parameter in the modified residual method [Hudson and Thompson, 1998]. Since no ozonesonde measurements are available at this location, it is derived using the climatological TCO over the South Atlantic, has a seasonal cycle similar to the climatology and is assumed constant with latitude in the tropics. The results from the convective-cloud differential method also show little seasonal variation over the equatorial dateline [Ziemke and Chandra, 1999]. In contrast, our retrievals show significant monthly and spatial variation at the dateline during DN97 (Figure 5a). Near the equator $\left(4^{\circ} \mathrm{N}-4^{\circ} \mathrm{S}\right)$, TCO is highest during 

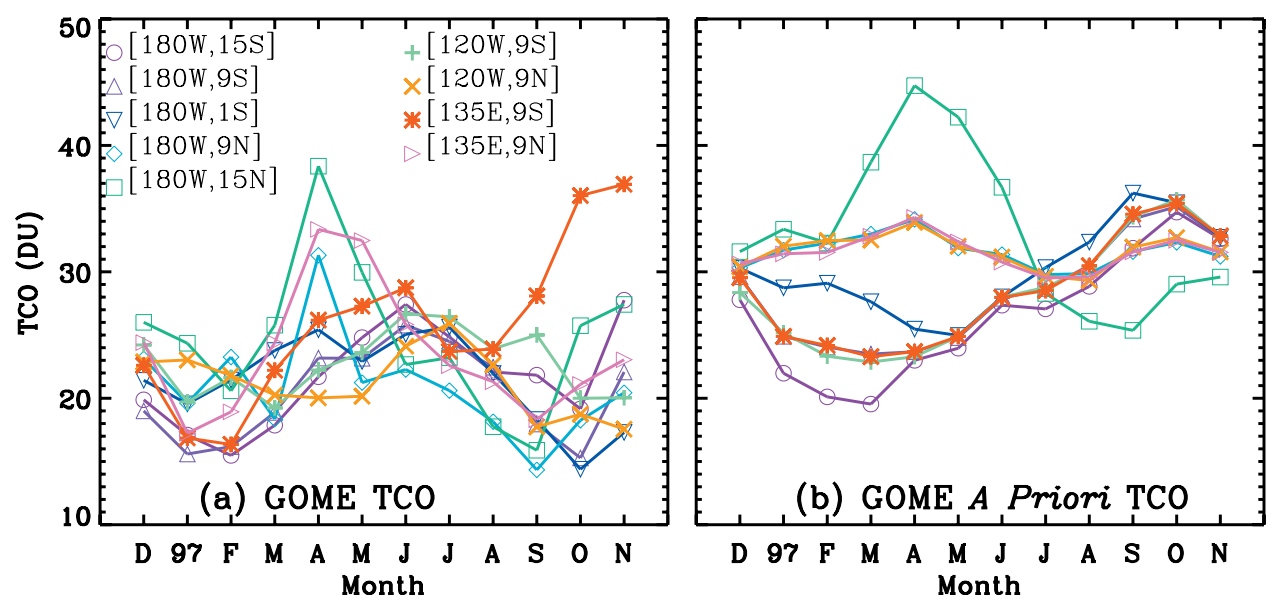

Figure 5. Monthly variation of (a) GOME tropospheric column ozone (TCO) and (b) its a priori TCO at selected locations over the Pacific.

April-July ( $\sim 25$ DU) and lowest during SeptemberNovember ( $\sim 15$ DU). With increasing latitude north of the equator, the TCO peak shifts to April (Figure 4). The maximum TCO is $\sim 30 \mathrm{DU}$ at $9^{\circ} \mathrm{N}$ and $\sim 40 \mathrm{DU}$ at $15^{\circ} \mathrm{N}$ (April) while the minimum TCO is $\sim 15$ DU (September). South of the equator, TCO gradually increases with increasing latitude in November due to the transport of subtropical high-ozone air (also in Figure 2c and Figures $3 \mathrm{e}$ and $3 \mathrm{f}$ ). The TCO peak in November is $\sim 25-28$ DU at $10^{\circ} \mathrm{S}-15^{\circ} \mathrm{S}$, comparable to the broad May-July maximum. The significant variation at the dateline reveals an important source of error in the modified residual method especially in the northern tropics [Hudson and Thompson, 1998], as was also noted in Peters et al. [2004].

[23] The wave-1 structure weakens in the extratropics. Relatively high TCO (compared to high-latitudes and the tropics) occurs at $30^{\circ} \mathrm{N} / \mathrm{S}$, i.e., near to the downward branches of the Hadley circulation. It is usually more uniformly distributed throughout the globe, including the Pacific and Atlantic, except over high terrains such as the Tibetan Plateau and the Rocky mountains. In the northern hemisphere, bands of enhanced TCO (36-48 DU) protrude at $25^{\circ} \mathrm{N}-40^{\circ} \mathrm{N}$ during April-July. Slightly higher values occur over the Pacific and Atlantic in April-May and from Southeast United States to Europe and Asian Pacific rim in June and July. In the southern hemisphere, bands of enhanced TCO (33-45 DU) occur at $25^{\circ} \mathrm{S}-35^{\circ} \mathrm{S}$ during September-November with slightly smaller values from the Eastern Pacific to the Atlantic. The above banded structures at $\sim 30^{\circ} \mathrm{N} / \mathrm{S}$ become weaker with the decrease in TCO in the north during November-December and in the south during January-June. As with the low TCO over the tropical Pacific, these banded structures also migrate with ITCZ, especially in the northern hemisphere. For example, the northern zonal band is mainly south of $30^{\circ} \mathrm{N}$ in MarchMay (MAM) and high TCO values are extended to some subtropical regions $\left(10^{\circ} \mathrm{N}-20^{\circ} \mathrm{N}\right.$, e.g., from the Southern Arabian Peninsula to Central Pacific). In JJA, the northern zonal band is mainly north of $30^{\circ} \mathrm{N}$. Fishman et al. [2003] and Chandra et al. [2003] also derive TCO at mid-latitudes, up to $30^{\circ} \mathrm{N} / \mathrm{S}$ and $50^{\circ} \mathrm{N} / \mathrm{S}$, respectively. Both methods usually show less zonal contrast outside the tropics and bands of enhanced ozone near $30^{\circ} \mathrm{N} / \mathrm{S}$. However, our results neither show the regional TCO maxima over the continents (e.g., North India, Eastern China, Eastern US) as seen in Fishman et al. [2003], nor the pronounced land/ocean contrast north of $30^{\circ} \mathrm{N}$ evident in Chandra et al. [2004]. The above mid-latitude banded structure is also supported in the assimilated global distribution of TCO (they only show TCO for September) with a global chemistry-transport model [Lamarque et al., 2002].

[24] TCO in the subtropics and mid-latitudes $\left(20^{\circ} \mathrm{S}-\right.$ $35^{\circ} \mathrm{S}, 15^{\circ} \mathrm{N}-50^{\circ} \mathrm{N}$ ) usually displays distinct seasonal cycles. In the southern mid-latitudes, TCO maximizes in September-November and minimizes in April-June. Over the South Pacific and Indian Ocean, however, GOME TCO shows small monthly variation during January-June. In the northern subtropics $\left(\sim 15^{\circ} \mathrm{N}-30^{\circ} \mathrm{N}\right.$, excluding regions from the Eastern Pacific to Northern Africa), TCO is highest in the spring and lowest in the summer (July-September). The summer minimum is especially evident over Southeast Asia and India with TCO values of 15-24 DU. There is another minimum in February. In the northern mid-latitudes $\left(>30^{\circ} \mathrm{N}-35^{\circ} \mathrm{N}\right)$, TCO peaks in May-July and is lowest during November-December. The above seasonal cycles in the northern hemisphere and the transition of a spring maximum at lower latitudes to a summer maximum at higher latitudes are consistent with observations and analyses along the Asian Pacific rim [Liu et al., 2002; Oltmans et al., 2004]. The spring maximum over Southeast Asia results primarily from downward stratospheric transport and photochemical production in the upper troposphere, and Southeast Asia biomass burning in the lower troposphere; the summer maximum at higher latitudes is due primarily to the strong photochemical production with ozone precursors from Asian pollution [Liu et al., 2002; Oltmans et al., 2004].

[25] The TCO values are usually $<30 \mathrm{DU}$ south of $\sim 35^{\circ} \mathrm{S}$ with a zonal variability of $<3 \mathrm{DU}$; the slightly large zonal variability at $70^{\circ} \mathrm{S}-80^{\circ} \mathrm{S}$ is mainly due to the variation in surface altitude. During November-March, the TCO distribution displays laminar structures with latitudinal gradients; TCO gradually decreases from 21-24 DU at mid-latitudes to 3-9 DU in the polar regions. The TCO shows different seasonal cycles from that at $20^{\circ} \mathrm{S}-30^{\circ} \mathrm{S}$, highest during July-September and lowest during December-March. This 

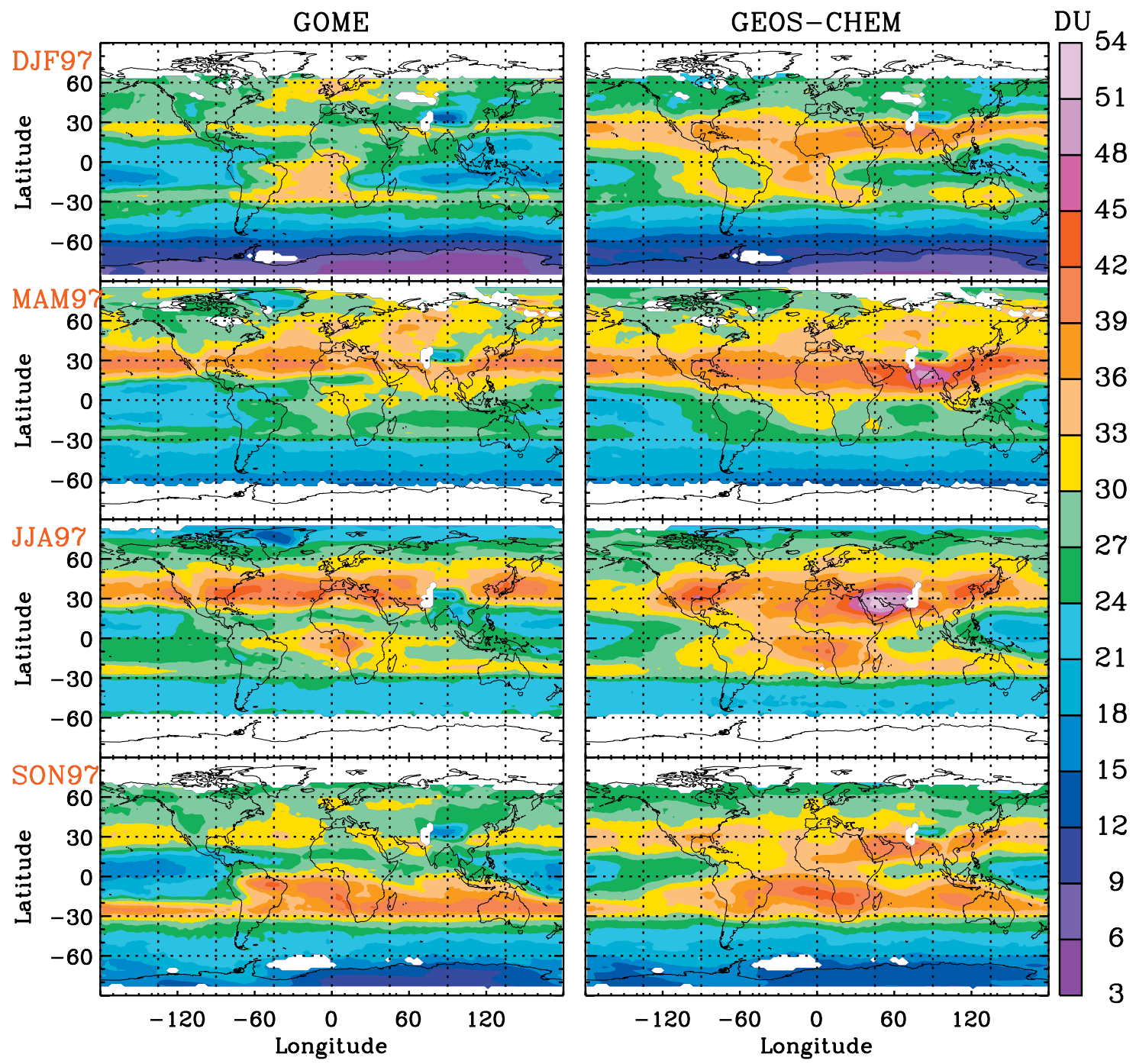

Figure 6. Comparison of seasonal average GOME and GEOS-CHEM (convolved with GOME averaging kernels) tropospheric column ozone from December 1996 to November 1997.

seasonal cycle becomes weaker at lower latitudes. Compared to the TCO at southern high-latitudes, the TCO at northern high-latitudes $\left(>60^{\circ} \mathrm{N}\right)$ is much larger and shows stronger zonal variability. Scattered high TCO values of 36-45 DU can be seen in January-April. Low TCO values of $18-24$ DU occur at $\sim 70^{\circ} \mathrm{N}$ north in JJA with small zonal variability except for persistent low TCO values over highterrain Greenland.

\section{Comparison With GEOS-CHEM Tropospheric Column Ozone}

[26] Figure 6 compares the seasonal average TCO between GOME and GEOS-CHEM (convolved with GOME AKs) for four seasons: December 1996-February 1997 (DJF), March-May 1997 (MAM), June-August 1997 (JJA), September-November 1997 (SON). The overall structures are similar: both show the tropical wave-1 pattern, more uniform distribution of TCO at $\sim 30^{\circ} \mathrm{N} / \mathrm{S}$, and generally similar spatiotemporal variations at middle to high latitudes (especially $35^{\circ} \mathrm{S}$ south). In DJF, GEOS-CHEM
TCO also has low values from the Central Pacific to Southern Africa $\left(10^{\circ} \mathrm{S}-20^{\circ} \mathrm{S}\right)$. There are similar enhancements from March 1997 through November 1997 over Indonesia (also in Figure 2a). At $\sim 30^{\circ} \mathrm{N}$, both show high TCO of 39-45 DU over Southeastern USA and its outflow, and over the region of East Asia outflow in JJA. The location and shape of high TCO features (36-45 DU) in the southern hemisphere and its spatiotemporal variation during JJA and SON are very similar. Globally, GOME TCO agrees well with GEOS-CHEM TCO, with negative biases of $<2 \pm 4$ DU and correlation coefficients $(r)$ in the range of $0.82-0.90$ for all seasons. The agreements are much better in the southern hemisphere, with negative biases of $<1.2 \pm 2.1 \mathrm{DU}$ and $r$ between 0.94 and 0.98 . In the northern hemisphere, the negative biases are $<4.3 \pm$ 4.6 DU and $r$ is within $0.62-0.81$. Figure 7 shows the distributions of these differences to be $< \pm 5$ DU in most regions, i.e., within the retrieval uncertainties and monthly variation of GOME and GEOS-CHEM TCO.

[27] Despite similar overall characteristics, significant differences exist between the two sets of global results. 

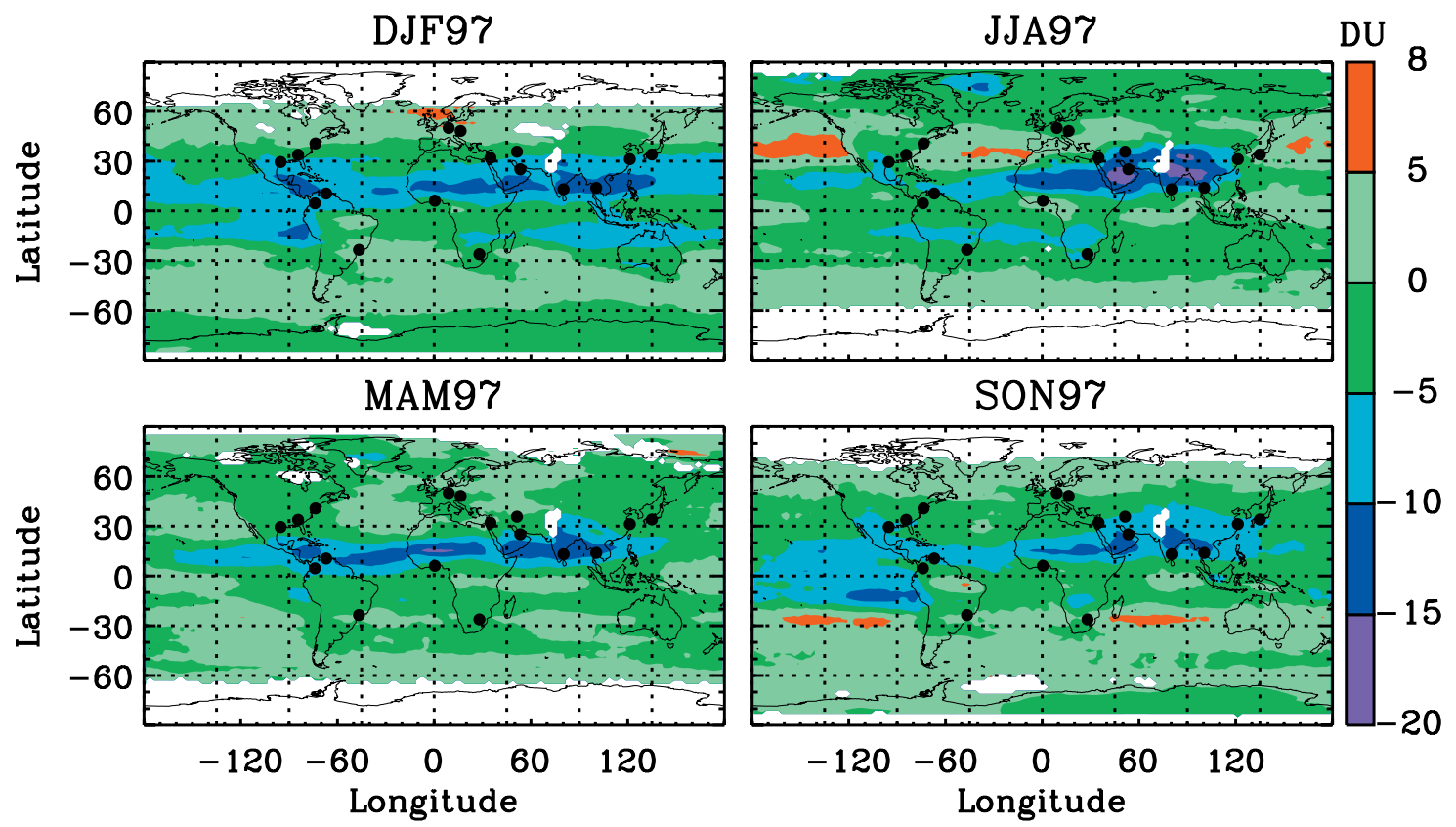

Figure 7. Seasonal average differences between GOME and GEOS-CHEM tropospheric column ozone values shown in Figure 6. Solid circles indicate the locations of MOZAIC measurements.

During all seasons, the northern banded structures are broader in the GEOS-CHEM simulation and extend to some subtropical and tropical areas; GOME TCO is consistently smaller by 5-20 DU over these regions. During MAM, GEOS-CHEM TCO shows a zonal maximum of $>42$ DU over India and Southeast Asia. This feature is not present in the GOME retrievals; the GEOSCHEM values are 5-15 DU higher. In JJA and SON, GEOS-CHEM TCO displays a zonal maximum over the Middle East. Li et al. [2001] attribute this to the complex interplay of dynamical and chemical factors, and of anthropogenic and natural influences. GOME retrievals do not show this elevated feature over this region, and the TCO is low (18-27 DU) over India and Southeast Asia. Thus GOME retrievals are smaller by 5-20 DU. Model overestimates of $\sim 10$ DU in India and Southeast Asia have been reported previously [Law et al., 2000; Lal and Lawrence, 2001; Martin et al., 2002a], the most likely causes of which are overestimates of $\mathrm{NO}_{\mathrm{x}}$ emission inventories and difficulties in resolving fine-scale processes (e.g., coastal dynamics or ozone titration by $\mathrm{NO}_{\mathrm{x}}$ in the urban plume) [Martin et al., 2002a, and references therein]. In addition, some of the GM/GC biases over the northern tropics and subtropics may be caused by the dust optical properties used in the retrievals. The $\mathrm{GM} / \mathrm{GC}$ biases are reduced by $30-40 \%$ over these regions in July 1997 if excluding aerosols in the retrievals. Because evaluation of dust aerosol optical depths does not show obvious dust overestimate over this region [Ginoux et al., 2001; Chin et al., 2002], we suspect that the improvement in GM/GC consistency without aerosols could derive from the use of monthly-mean fields (rather than daily), and from the low single scattering albedo of Patterson et al. [1977] used in the retrievals as evidenced by Colarco et al. [2002] that the dust single scattering albedo could be higher.
[28] In DJF and SON, the trapezoidal plume in GEOSCHEM extends to the Eastern Pacific, while GOME retrievals show large zonal gradients across the coast line and the Andes and are 5-15 DU smaller over the Eastern Pacific. This bias is probably due to the inadequate spatial resolution of the GEOS-CHEM simulation to resolve the topography of the Andes. GOME retrievals show negative biases of 5-10 DU over the Southwestern Pacific in DJF (also in Figure $2 \mathrm{a})$, from South America to Southern Africa $\left(10^{\circ} \mathrm{S}-\right.$ $20^{\circ} \mathrm{S}$ ) and over Greenland in JJA. Positive biases of 5-8 DU occasionally occur over the Pacific in JJA, at southern midlatitudes in SON, and northern high latitudes in DJF. Those positive biases at mid-latitudes may reflect the a priori influence in GOME retrievals from the used zonal-invariant a priori climatology.

[29] Figure 8 shows the correlation coefficients between GOME and GEOS-CHEM monthly mean TCO during DN97. The correlation coefficient indicates the consistency in seasonal cycles. Similar seasonal variations $(r>0.6)$ occurs at most regions except over the equatorial Central and Eastern Pacific, some northern tropical areas, the Eastern Pacific off the west coast of the United States, and northern high latitudes. For example, the poor correlation over the equatorial Pacific is due to that GOME TCO exhibits an annual variation of $\sim 10$ DU (Figure 5a), while GEOSCHEM TCO generally shows no clear seasonal cycle with a smaller annual variation $(<5 \mathrm{DU})$.

\section{Evaluation of GOME and GEOS-CHEM With MOZAIC Measurements}

[30] Some of the large GM/GC biases occur at regions where there are few ozonesonde measurements, e.g., Southeast Asia and the Middle East. However, MOZAIC measurements fill in the gap at least over some of these regions. 


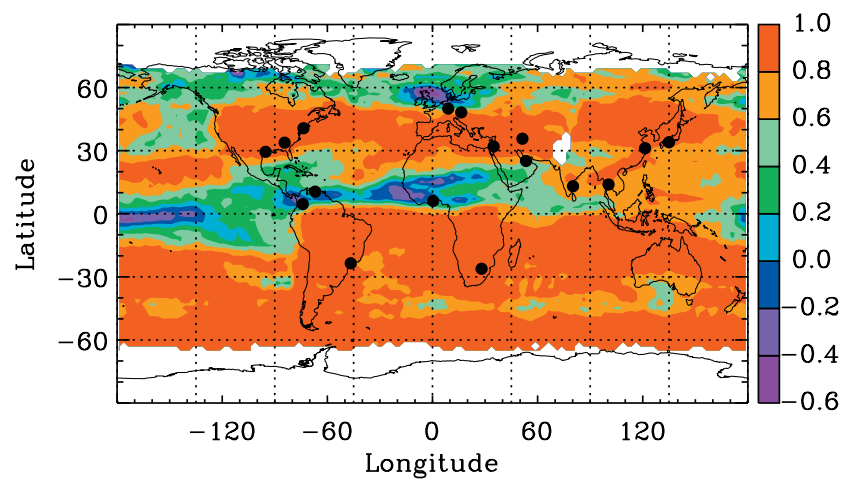

Figure 8. Correlation coefficients between GOME and GEOS-CHEM monthly mean tropospheric column ozone from December 1996 to November 1997. Solid circles indicate the locations of MOZAIC measurements.

We examine the GM/GC biases with MOZAIC measurements at 17 locations (Table 1, arranged by region and latitude, Figures 7 and 8), with special focus on regions with significant discrepancies.

[31] The MOZAIC program collects ozone and water vapor data using automatic sensors installed on board five long range Airbus A340 aircrafts [Marenco et al., 1998] (http://www.aero.obs-mip.fr/mozaic). The ozone sensor is a dual-beam ultraviolet absorption instrument with a measurement accuracy of $2 \mathrm{ppbv}+2 \%$ [Thouret et al., 1998]. Ozone profiles are recorded during takeoff and landing, within a horizontal distance of $\sim 350 \mathrm{~km}$ from the airport. Vertical coverage ranges from ground to a maximum altitude of $\sim 12 \mathrm{~km}$ (i.e., cruise altitude). Intercomparisons with ozonesonde observations have demonstrated the capability of MOZAIC data to make reliable and accurate ozone measurements, although larger discrepancies sometimes occur in the boundary layer and upper troposphere due to local pollution and spatial difference [Thouret et al., 1998].
[32] This study relies here on an analysis of the MOZAIC ozone profile data by J. A. Logan and I. A. Megretskaia (manuscript in preparation, 2006), who provided monthly mean ozone profiles with vertical resolution of $0.5 \mathrm{~km}$ for the various MOZAIC locations in Table 1. Only locations for which most months had more than 10 profiles per month were used. Average profiles were derived from data during 1994-2004. However, this period is not sampled evenly at most locations except for those in Europe where the flights originate, because the routes flown are changed on an irregular basis.

[33] The MOZAIC profiles do not always reach the tropopause, particularly in the subtropics and tropics, and some of the surface altitudes differ from those used in the GOME retrievals. We adjust the MOZAIC profiles using the GOME profiles above the altitude reached by the aircraft so that we can compare the TCO from the surface altitudes of the MOZAIC data to the tropopause. A similar correction is made to the GEOS-CHEM output to correct for differences in the surface altitude. We do not convolve monthly mean MOZAIC data with GOME AKs because the altitude grids of GOME AKs vary from day to day. However, this should not significantly affect the following results since the mean TCO change due to convolving GEOS-CHEM data is typically $<3$ DU at these locations. Figure 9 compares various measurements of TCO and a priori TCO used in GOME retrievals with comparison statistics, Mean Biases (MBs), $1 \sigma$ Standard Deviations (SDs), and correlation coefficients, summarized in Table 2. Figure 10 compares various tropospheric ozone profiles for selected months and locations.

[34] At Johannesburg (Figure 9k) and most of the locations north of $29^{\circ} \mathrm{N}$, TCO from both GOME and GEOSCHEM usually agrees and correlates well with MOZAIC TCO, to within $1 \sigma$ of the measurements. At Sao Paulo (Figure 9a), GOME TCO agrees well with GEOS-CHEM TCO, but both are systematically higher than MOZAIC TCO by $\sim 5$ DU. At Teheran during July-September (Figure 9o), opposite biases relative to MOZAIC TCO

Table 1. Locations of MOZAIC Measurements

\begin{tabular}{|c|c|c|c|c|}
\hline Region & Location & Lon, $^{\circ}$ & Lat, ${ }^{\circ}$ & Comments \\
\hline \multirow[t]{6}{*}{ South and North America } & Sao Paulo & -46.7 & -23.5 & \multirow{6}{*}{$<10$ profiles in May-Jul } \\
\hline & Bogota & -74.0 & 4.6 & \\
\hline & Caracas & -67.0 & 10.5 & \\
\hline & Houston & -95.2 & 29.5 & \\
\hline & Atlanta & -84.4 & 33.8 & \\
\hline & New York & -73.6 & 40.7 & \\
\hline \multirow[t]{4}{*}{ Southeast Asia } & Madras & 80.2 & 13.1 & \multirow[t]{4}{*}{$<10$ profiles in Jul } \\
\hline & Bangkok & 100.5 & 13.9 & \\
\hline & Shanghai & 121.3 & 31.2 & \\
\hline & Osaka & 135.0 & 34.0 & \\
\hline \multirow[t]{2}{*}{ Africa } & Johannesburg & 28.0 & -26.2 & \multirow{7}{*}{$\begin{array}{l}<10 \text { profiles in Jan } \\
<10 \text { profiles in Nov-Feb }\end{array}$} \\
\hline & Accra $^{\mathrm{a}}$ & 0.4 & 6.1 & \\
\hline \multirow[t]{3}{*}{ Mid-east } & Dubai $^{\mathrm{b}}$ & 53.4 & 25.1 & \\
\hline & Tel Aviv & 34.9 & 32.0 & \\
\hline & Teheran & 51.3 & 35.7 & \\
\hline \multirow{2}{*}{ Northern Europe } & Vienna & 16.4 & 48.2 & \\
\hline & Frankfurt & 9.0 & 50.0 & \\
\hline
\end{tabular}

\footnotetext{
${ }^{a}$ All measurements at Lagos $\left(6.6^{\circ} \mathrm{N}, 3.3^{\circ} \mathrm{E}\right)$, Accra $\left(5.6^{\circ} \mathrm{N}, 0.1^{\circ} \mathrm{W}\right)$, and Abidjan $\left(5.4^{\circ} \mathrm{N}, 4^{\circ} \mathrm{W}\right)$. The center location is the geolocation weighted by the number of profiles.

${ }^{\mathrm{b}}$ All measurements at Dubai $\left(25.3^{\circ} \mathrm{N}, 55.4^{\circ} \mathrm{E}\right)$, Abu Zaby $\left(24.4^{\circ} \mathrm{N}, 54.6^{\circ} \mathrm{E}\right)$, Riyadh $\left(25.0^{\circ} \mathrm{N}, 46.7^{\circ} \mathrm{E}\right)$, and Dhahran $\left(26.3^{\circ} \mathrm{N}\right.$, $\left.50.1^{\circ} \mathrm{E}\right)$.
} 
(a) Sao Paulo (23.5S,46.7W)

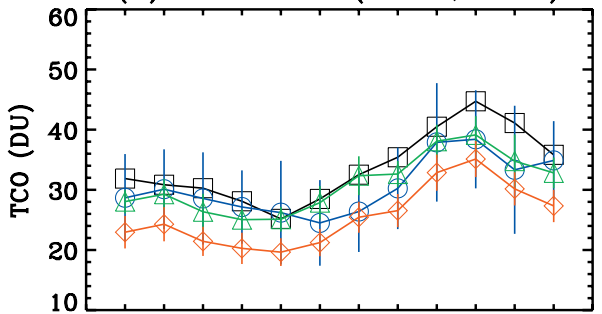

(d) Houston $(29.5 \mathrm{~N}, 95.2 \mathrm{~W})$

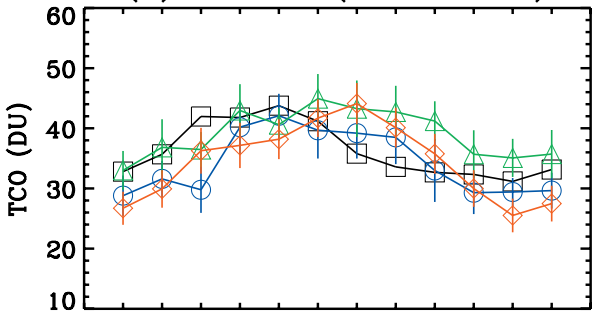

(g) Madras $(13.1 \mathrm{~N}, 80.2 \mathrm{E})$

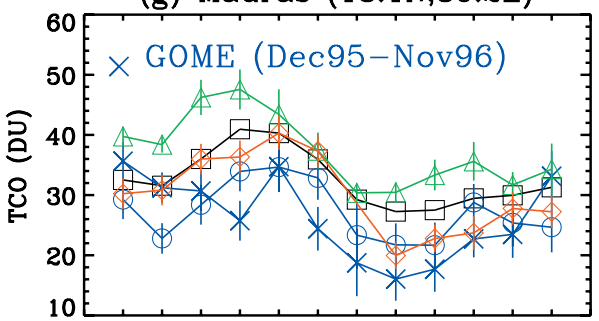

(j) Osaka $(34.0 \mathrm{~N}, 135.0 \mathrm{E})$

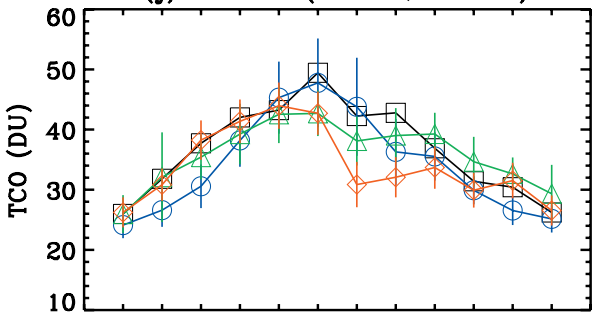

(m) Dubai $(25.1 \mathrm{~N}, 53.4 \mathrm{E})$

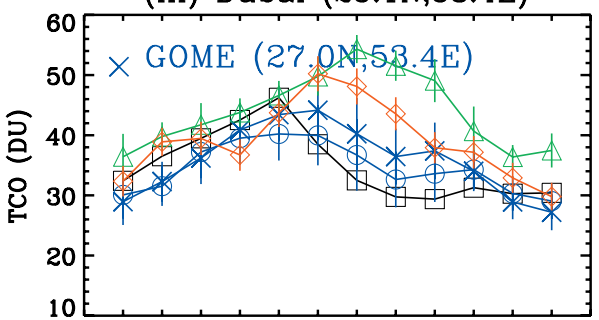

(p) Vienna $(48.2 \mathrm{~N}, 16.4 \mathrm{E})$

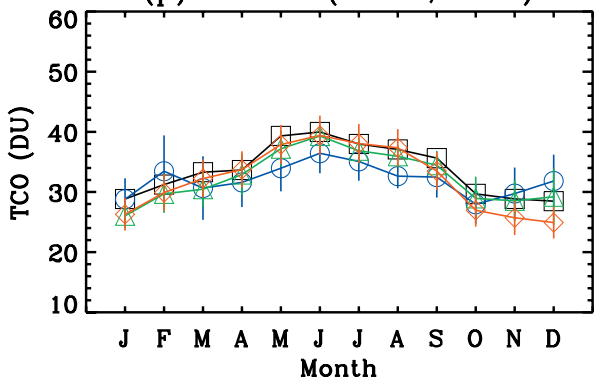

(b) Bogota $(4.6 \mathrm{~N}, 74.0 \mathrm{~W})$

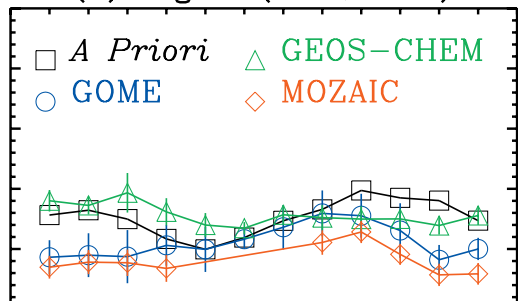

(e) Atlanta $(33.8 \mathrm{~N}, 84.4 \mathrm{~W})$

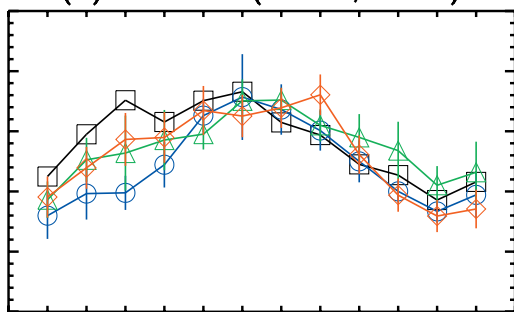

(h) Bangkok $(13.9 \mathrm{~N}, 100.5 \mathrm{E})$

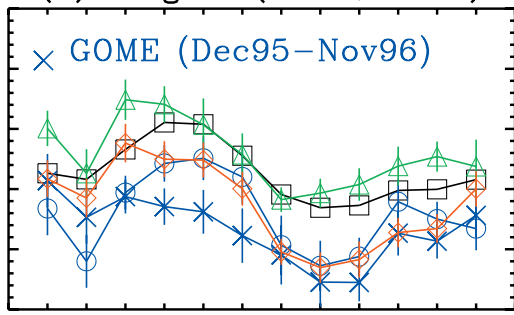

(k) Johannesbourg (26.2S,28.0E)

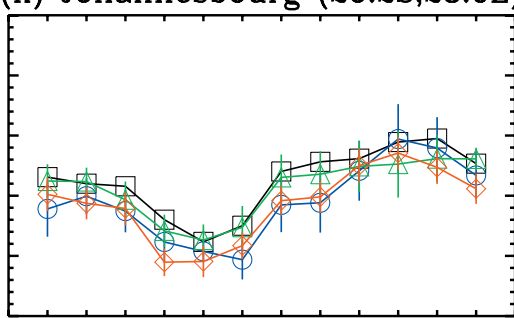

(n) Tel Aviv (32.0N,34.9E)

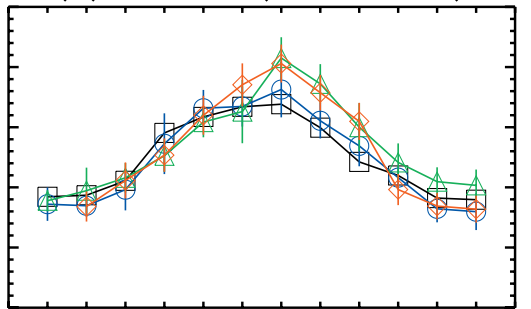

(q) Frankfurt $(50.0 \mathrm{~N}, 9.0 \mathrm{E})$

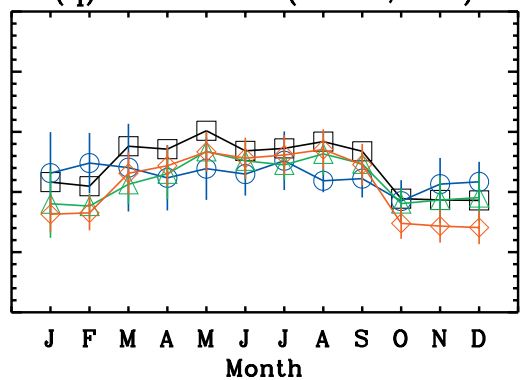

(c) Caracas $(10.5 \mathrm{~N}, 67.0 \mathrm{~W})$

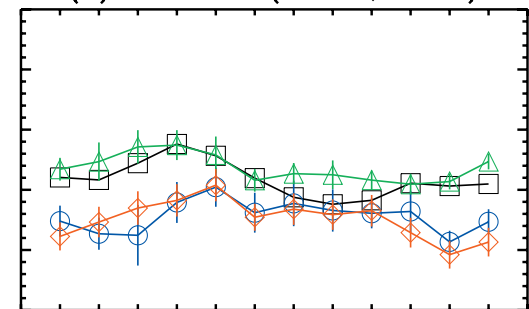

(f) New York $(40.7 \mathrm{~N}, 73.6 \mathrm{~W})$

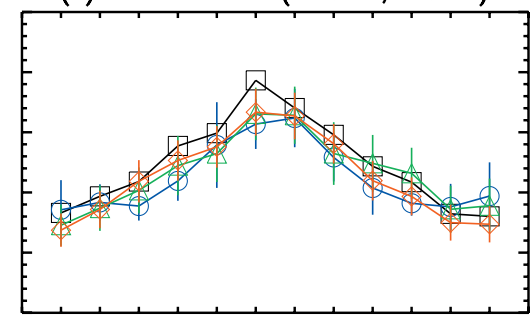

(i) Shanghai $(31.2 \mathrm{~N}, 121.3 \mathrm{E})$

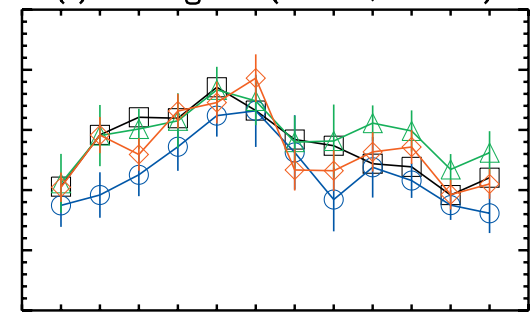

(l) Accra $(6.1 \mathrm{~N}, 0.4 \mathrm{E})$

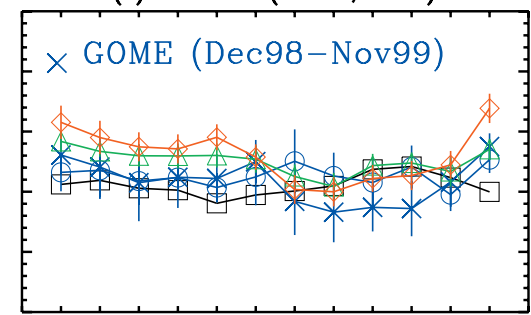

(o) Teheran $(35.7 \mathrm{~N}, 51.3 \mathrm{E})$

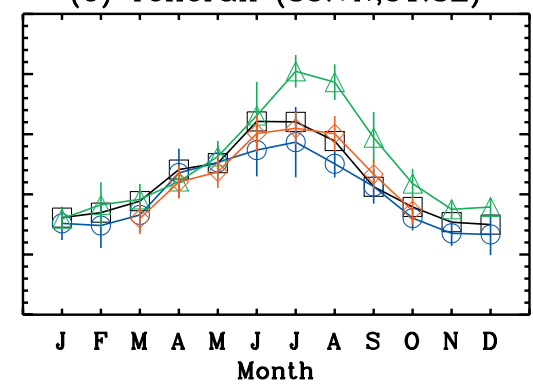

Figure 9. Comparison of GOME, GOME a priori, GEOS-CHEM, and MOZAIC tropospheric column ozone (TCO) at MOZAIC locations. GOME TCO for other years or adjacent locations is indicated by crosses. Error bars show $1 \sigma$ of the monthly means. 
Table 2. Mean Biases, Standard Deviations $(1 \sigma)$ in DU, and Correlation Coefficients $(r)$ Between GOME, GEOS-CHEM, and MOZAIC Tropospheric Column Ozone

\begin{tabular}{|c|c|c|c|c|c|c|}
\hline \multirow[b]{2}{*}{ Location } & \multicolumn{2}{|c|}{ GOME-GEOS } & \multicolumn{2}{|c|}{ GOME-MOZAIC } & \multicolumn{2}{|c|}{ GEOS-MOZAIC } \\
\hline & $\operatorname{Bias} \pm 1 \sigma$ & $r$ & $\operatorname{Bias} \pm 1 \sigma$ & $r$ & $\operatorname{Bias} \pm 1 \sigma$ & $r$ \\
\hline Sao Paulo & $-0.4 \pm 2.5$ & 0.86 & $4.9 \pm 2.0$ & 0.91 & $5.3 \pm 0.8$ & 0.99 \\
\hline Bogota & $-4.5 \pm 3.7$ & -0.36 & $2.8 \pm 1.4$ & 0.89 & $7.9 \pm 3.2$ & -0.19 \\
\hline Caracas & $-8.0 \pm 3.3$ & 0.10 & $0.5 \pm 2.3$ & 0.71 & $8.6 \pm 2.9$ & 0.50 \\
\hline Houston & $-4.8 \pm 2.4$ & 0.89 & $-0.1 \pm 3.5$ & 0.83 & $4.6 \pm 3.1$ & 0.91 \\
\hline Atlanta & $-3.0 \pm 2.9$ & 0.93 & $-1.8 \pm 3.6$ & 0.87 & $1.2 \pm 3.9$ & 0.85 \\
\hline New York & $-0.8 \pm 2.4$ & 0.92 & $-0.2 \pm 2.7$ & 0.93 & $0.6 \pm 1.9$ & 0.96 \\
\hline Madras & $-10.1 \pm 4.0$ & 0.74 & $-2.6 \pm 3.9$ & 0.82 & $7.8 \pm 3.9$ & 0.81 \\
\hline Bangkok & $-10.1 \pm 3.7$ & 0.81 & $-1.7 \pm 4.7$ & 0.75 & $8.4 \pm 3.1$ & 0.90 \\
\hline Shanghai & $-6.2 \pm 3.1$ & 0.85 & $-3.9 \pm 3.1$ & 0.86 & $2.3 \pm 2.9$ & 0.89 \\
\hline Osaka & $-1.8 \pm 4.1$ & 0.92 & $0.2 \pm 5.5$ & 0.75 & $1.9 \pm 3.5$ & 0.82 \\
\hline Johannesburg & $-2.1 \pm 2.8$ & 0.91 & $0.5 \pm 2.1$ & 0.95 & $2.5 \pm 2.1$ & 0.95 \\
\hline Accra & $-2.4 \pm 2.5$ & 0.14 & $-3.4 \pm 4.5$ & 0.14 & $-1.0 \pm 2.7$ & 0.90 \\
\hline Dubai & $-9.4 \pm 5.1$ & 0.57 & $-4.6 \pm 4.6$ & 0.71 & $4.7 \pm 3.3$ & 0.86 \\
\hline Tel Aviv & $-2.2 \pm 2.8$ & 0.93 & $-1.3 \pm 2.5$ & 0.97 & $1.0 \pm 2.7$ & 0.96 \\
\hline Teheran & $-5.0 \pm 4.4$ & 0.88 & $-1.2 \pm 2.3$ & 0.93 & $4.7 \pm 3.2$ & 0.94 \\
\hline Vienna & $-0.4 \pm 2.5$ & 0.85 & $-0.1 \pm 3.7$ & 0.80 & $0.3 \pm 1.9$ & 0.95 \\
\hline Frankfurt & $0.7 \pm 3.5$ & 0.28 & $1.5 \pm 4.9$ & 0.44 & $0.8 \pm 2.3$ & 0.95 \\
\hline
\end{tabular}

(GEOS-CHEM higher by 5-9 DU, GOME smaller by $2-$ 5 DU) lead to GM/GC differences of 8-14 DU. Similarly, over Shanghai during August-December, opposite biases cause the 5-10 DU GM/GC discrepancies. GEOS-CHEM
TCO values are 5-10 DU higher than MOZAIC values over Houston and Atlanta during some fall and winter months, while GOME TCO shows negative biases of 410 DU for some months in February-April at Houston, (a) Houston, March

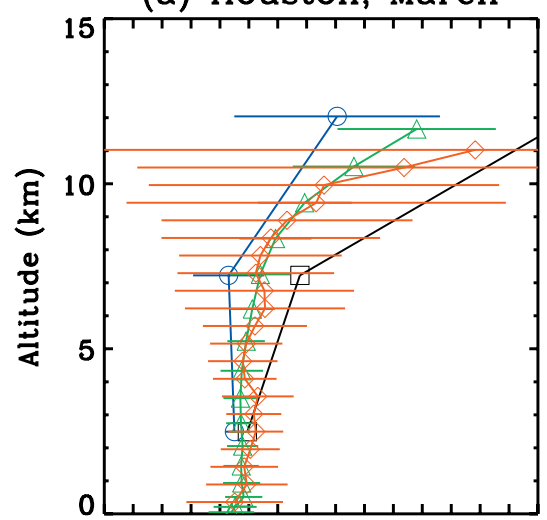

(d) Shanghai, February

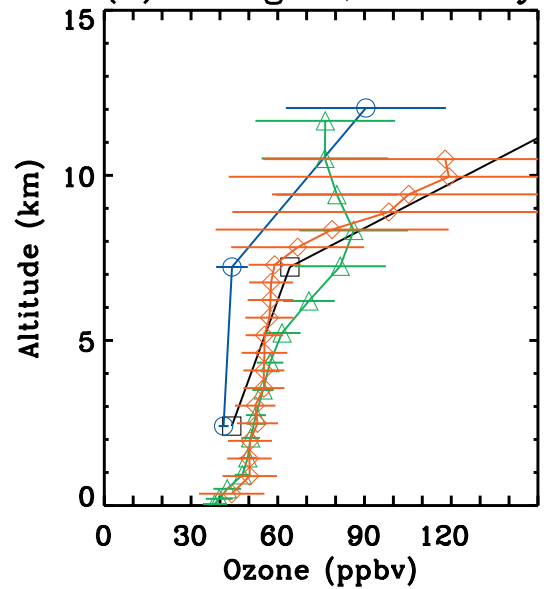

(b) Madras, February

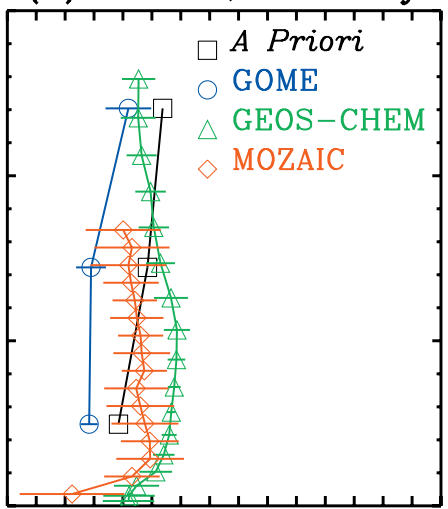

(e) Accra, January

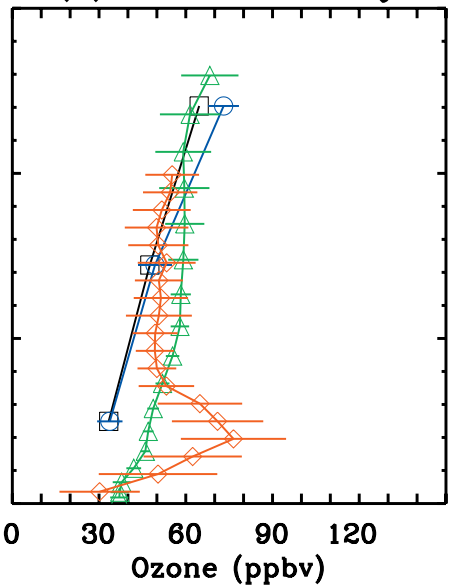

(c) Bangkok, February

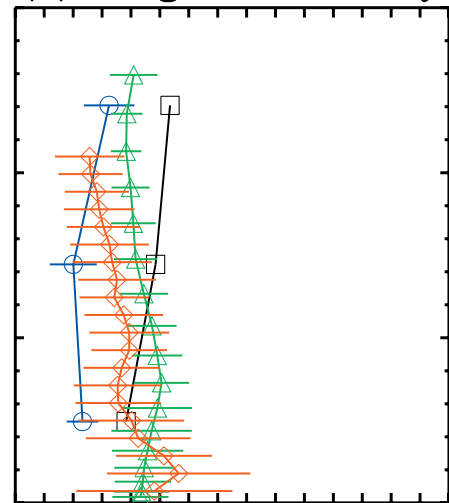

(f) Dubai, August

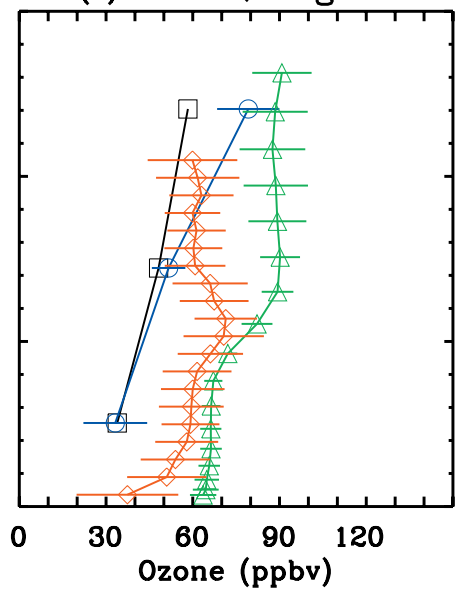

Figure 10. Comparison of monthly mean tropospheric ozone profiles from GOME, GOME a priori, GEOS-CHEM, and MOZAIC for selected locations and months. Error bars show $1 \sigma$ of the monthly means. 
Atlanta, Shanghai, and Osaka (Figures 9d and 9e and Figures $9 \mathrm{i}$ and $9 \mathrm{j}$ ). These differences mainly occur in the upper troposphere (Figures 10a and 10d); they are not caused by the a priori influence since the a priori values show positive biases. These upper tropospheric biases may be attributed to the large mid-latitude spatiotemporal variability from stratospheric influence during the winter and spring [Newchurch et al., 2003b; Oltmans et al., 2004] and the spatiotemporal sampling difference between GOME and MOZAIC data [Thouret et al., 1998]. GOME TCO is also 13 DU higher than MOZAIC TCO over Osaka in July. This bias could be due to the large spatial resolution of GOME retrievals and the large spatial gradient over this region (see Figure 4). Figure 9j (crosses) shows that the TCO at a next grid $\left(33.0^{\circ} \mathrm{N}\right.$, $136.2^{\circ} \mathrm{E}$ ) agrees well with MOZAIC TCO to within 4 DU. At Frankfurt, GOME TCO shows negative biases in May and September and positive biases during NovemberFebruary with respect to both MOZAIC and GEOS-CHEM TCO, resulting in poor correlation. The seasonal pattern of bias likely results from the difficulty in differentiating snow/ice and clouds in GOME retrievals.

[35] At the two Central America locations, Bogota and Caracas, there is a poor $\mathrm{GM} / \mathrm{GC}$ correlation and large differences of 5-15 DU occur during most seasons (Figures $9 \mathrm{~b}$ and $9 \mathrm{c}$ ). Although the a priori TCO is very different from the MOZAIC TCO, GOME retrievals correlate and agree with MOZAIC measurements to within 5 DU (MBs $<2.8 \pm 2.3$ DU). GEOS-CHEM TCO shows poor correlation and consistently positive biases of $2-$ 13 DU (MBs >7.9 \pm 2.9 DU) relative to MOZAIC data, suggesting problems in the GEOS-CHEM simulations over this region.

[36] Significant negative GM/GC biases of 5-18 DU occur over Madras and Bangkok through most months although both show consistent seasonal cycles with MOZAIC observations (Figures 9g and 9h). GEOS-CHEM TCO is usually 5-14 DU higher than MOZAIC TCO (with MBs of $>7.8 \pm 3.1 \mathrm{DU}$ ), indicating model problems over Southeast Asia as discussed in Martin et al. [2002a]. GOME TCO usually agrees well with MOZAIC TCO to within 5 DU. However, negative biases of 7-10 DU occur over Madras and Bangkok in February and March, originating mostly from the lower and middle troposphere (Figures $9 \mathrm{~g}$ and $9 \mathrm{~h}$ and Figures $10 \mathrm{~b}$ and 10c). These negative GOME biases are clearly not due to the a priori influence because of much less or opposite biases in the a priori profiles. Some of these biases may be attributed to spatiotemporal variation and GOME/MOZAIC sampling differences. For example, GOME TCO during December 1995 to November 1996 (crosses in Figures 9g and 9h) agrees well with MOZAIC TCO at Madras in February and at Bangkok in January and February.

[37] Although the GM/GC biases over Accra remain within 5 DU, GOME TCO is poorly correlated with MOZAIC, GEOS-CHEM and a priori TCO (Figure 91). It is $\sim 8$ DU higher than MOZAIC TCO during December, January, and April. Figure 10e shows that MOZAIC ozone in January is 50 ppbv higher than GOME ozone in the lower troposphere due to biomass burning over Northern Africa [Martin et al., 2002a; Sauvage et al., 2005]. The marginal improvement in the retrieval over the a priori suggests that this negative bias is not caused by the reduced sensitivity to lower tropospheric ozone and the a priori influence alone since the retrieval still has some sensitivity to ozone at $\sim 2 \mathrm{~km}$ [Liu et al., 2005]. Since most MOZAIC measurements over Accra were made after 1998, inter-annual variation of TCO partly contributes to these biases. For example, GOME TCO in 1999 (crosses in Figure 91) shows a seasonal cycle consistent with MOZAIC TCO $(r=0.91)$ except that GOME TCO is smaller by $\sim 5$ DU during most months. The enhanced GOME TCO in July, non-existent in 1999, may be due to the transport of ozone from the southern tropics, which has been observed by MOZAIC data at Lagos [Sauvage et al., 2005]. The large latitudinal gradient in TCO over this region (Figure 4) and the poor spatial resolution of the retrievals may also contribute to the above biases.

[38] GOME TCO shows persistent negative biases relative to GEOS-CHEM TCO at Dubai (Figure 9m). Compared to MOZAIC TCO, GOME TCO shows negative biases of 7-11 DU in February and JJA; GEOS-CHEM TCO, on the other hand, shows positive biases of 6-11 DU in July-September, April, and December. The opposite biases lead to the 15-19 DU GM/GC differences in JJA. Figure 10f shows that the large GOME bias in July mainly occurs in the lower and middle troposphere. As is the case over Accra, this negative bias is not caused entirely by the a priori influence. The large latitude gradient (Figure 4) and the spatial domain difference between GOME and MOZAIC can partly account for the biases seen in GOME TCO. For example, GOME TCO at an adjacent grid point $\left(27^{\circ} \mathrm{N}, 53.4^{\circ} \mathrm{E}\right)$ agrees with MOZAIC TCO to better than 6-8 DU (within $1 \sigma$ of both measurements) in JJA (Figure 9m). In addition, some of the biases might be due to the dust optical properties as discussed in section 6; the bias in July is reduced by 3.5 DU when excluding aerosols in the retrievals.

\section{Summary}

[39] The global distribution of Tropospheric Column Ozone (TCO) is directly retrieved from satellite observations. The algorithm to retrieve TCO and ozone profiles $(0-60 \mathrm{~km})$ from the Global Ozone Monitoring Experiment (GOME) radiance spectra has been described in detail in a previous paper and the retrievals have been validated against ozonesonde measurements during 1996-1999. In order to reduce the stratospheric influence on tropospheric ozone, we have characterized the tropopause by combining the dynamic tropopause in the extratropics and the thermal tropopause near the equator. The retrievals clearly show the effects of convection, biomass burning, stratospheric intrusion, industrial pollution, and transport on TCO, and are able to capture the spatiotemporal evolution of TCO responding to regional and short time-scale events (e.g., the 1997-1998 El Niño episode, a 10-20 DU change of TCO within a few days).

[40] We present monthly mean global maps of GOME TCO during December 1996-November 1997 and compare the results with a 3D global tropospheric chemistry model (GEOS-CHEM). The overall structures are similar, with small biases of less than \pm 5 DU and consistent seasonal cycles in most regions, especially in the southern 
hemisphere. Both show the tropical wave-1 structure, similar seasonal variation over the tropical South Atlantic, nearly zonal bands of enhanced TCO of 36-45 DU at $20^{\circ} \mathrm{S}-30^{\circ} \mathrm{S}$ during the austral spring and at $25^{\circ} \mathrm{N}-45^{\circ} \mathrm{N}$ during boreal spring and summer, TCO of $<30$ DU zonally distributed at southern middle to high-latitudes, and latitudinal variations of TCO in DJF from $30 \mathrm{DU}$ at $30^{\circ} \mathrm{S}$ to $3 \mathrm{DU}$ at the South Pole. However, significant positive biases of 5-20 DU persistently occur at some northern tropical and subtropical regions (e.g., Central America, Southeast Asia, the Middle East). The evaluation of both GOME and GEOS-CHEM TCO with MOZAIC TCO, focusing on those critical regions, shows that the GOME retrievals usually agree with the MOZAIC measurements to within the monthly variability (e.g., Central America, Southeast Asia, Northern Middle East) and that some biases may be attributed to the spatiotemporal variation in TCO, reduced sensitivity to lower tropospehric ozone, dust optical properties used in the retrievals, and the large spatial resolution of GOME retrievals. The systematic overestimation in GEOS-CHEM TCO relative to MOZAIC data over Central America and Southeast Asia indicates problems in the model simulation in these regions.

[41] This study has focused on one year of TCO out of the available 5.5 year GOME data record, from July 1995 through December 2000 (http://www-cfa.harvard.edu/ atmosphere). In addition to TCO, this data set also contains 11-layer ozone profiles, total column ozone, and stratospheric column ozone. GOME observations since 2000 are subject to more severe instrument degradation and an external degradation correction to the radiance and irradiance data is necessary to ensure the same retrieval quality.

[42] This retrieval method can be applied to other nadirviewing satellite UV observations including those from the Scanning Imaging Absorption Spectrometer for Atmospheric Chartography (SCIAMACHY), the Ozone Monitoring Experiment (OMI), the future GOME-2 instruments (first to be launched in 2006) and the Ozone Mapping and Profiler Suite instrument (OMPS, first to be launched in 2008). With the superior spatial resolution and coverage of these instruments, global pictures of TCO can be resolved at much finer spatial scales and will significantly improve our current understanding about the sources, sinks, and transport of tropospheric ozone.

[43] Acknowledgments. This study is supported by NASA and by the Smithsonian Institution. We acknowledge the MOZAIC team and its funding agencies for the aircraft ozone measurements. We thank the NOAA-CIRES CDC for providing NCEP reanalysis data and the ECMWF team for providing ERA-40 data. We are thankful to L. Pfister and R. M. Yantosca for discussions on tropopause pressure, to H. Y. Liu and Q. B. Li for discussion on the ozone distribution, and to J. H. Kim for his comments to improve the paper.

\section{References}

Bertschi, I. T., D. Jaffe, L. Jaeglé, H. U. Price, and J. B. Dennison (2004), PHOBEA/ITCT 2002 airborne observations of transpacific transport of ozone, $\mathrm{CO}$, volatile organic compounds, and aerosols to the northeast Pacific: Impacts of Asian anthropogenic and Siberian boreal fire emissions, J. Geophys. Res., 109, D23S12, doi:10.1029/ 2003JD004328.

Bey, I., D. J. Jacob, J. A. Logan, and R. M. Yantosca (2001a), Asian chemical outflow to the Pacific: Origins, pathways, and budgets, J. Geophys. Res., 106, 23,097-23,114.
Bey, I., et al. (2001b), Global modeling of tropospheric chemistry with assimilated meteorology: Model description and evaluation, J. Geophys. Res., 106, 23,073-23,096.

Bhartia, P. K., R. D. McPeters, C. L. Mateer, L. E. Flynn, and C. Wellemeyer (1996), Algorithm for the estimation of vertical ozone profiles from the backscattered ultraviolet technique, J. Geophys. Res., 101(D13), 18,793-18,806.

Chance, K. V., J. P. Burrows, D. Perner, and W. Schneider (1997), Satellite measurements of atmospheric ozone profiles, including tropospheric ozone, from ultraviolet/visible measurements in the nadir geometry: a potential method to retrieve tropospheric ozone, J. Quant. Spectrosc. Radiat. Transfer, 57(4), 467-476.

Chandra, S., J. R. Ziemke, W. Min, and W. G. Read (1998), Effects of 1997-1998 El Nino on tropospheric ozone and water vapor, Geophys. Res. Lett., 25(20), 3867-3870.

Chandra, S., J. R. Ziemke, P. K. Bhartia, and R. V. Martin (2002), Tropical tropospheric ozone: Implications for dynamics and biomass burning, J. Geophys. Res., 107(D14), 4188, doi:10.1029/2001JD000447.

Chandra, S., J. R. Ziemke, and R. V. Martin (2003), Tropospheric ozone at tropical and middle latitudes derived from TOMS/MLS residual: Comparison with a global model, J. Geophys. Res., 108(D9), 4291, doi:10.1029/2002JD002912.

Chandra, S., J. R. Ziemke, X. Tie, and G. Brasseur (2004), Elevated ozone in the troposphere over the Atlantic and Pacific oceans in the Northern Hemisphere, Geophys. Res. Lett., 31, L23102, doi:10.1029/ 2004GL020821.

Chin, M., et al. (2002), Tropospheric aerosol optical thickness from the GOCART model and comparisons with satellite and sunphotometer measurements, J. Atmos. Sci., 59, 461-483.

Colarco, P. R., O. B. Toon, O. Torres, and P. J. Rasch (2002), Determining the UV imaginary index of refraction of Saharan dust particles from Total Ozone Mapping Spectrometer data using a three dimensional model of dust transport, J. Geophys. Res., 107(D16), 4289, doi:10.1029/ 2001JD000903.

Duncan, B. N., R. V. Martin, A. C. Staudt, R. Yecich, and J. A. Logan (2003), Interannual and seasonal variability of biomass burning emissions constrained by satellite observations, J. Geophys. Res., 108(D2), 4100, doi:10.1029/2002JD002378.

European Space Agency (ESA) (1995), The GOME users manual, ESA Publ. SP-1182, Publ. Div., ESTEC, Noordwijk, Netherlands.

Fiore, A. M., D. J. Jacob, I. Bey, R. M. Yantosca, B. D. Field, A. C. Fusco, and J. G. Wilkinson (2002), Background ozone over the United States in summer: Origin, trend, and contribution to pollution episodes, J. Geophys. Res., 107(D15), 4275, doi:10.1029/2001JD000982.

Fiore, A. M., D. J. Jacob, H. Liu, R. M. Yantosca, T. D. Fairlie, and Q. Li (2003a), Variability in surface ozone background over the United States: Implications for air quality policy, J. Geophys. Res., 108(D24), 4787, doi:10.1029/2003JD003855.

Fiore, A. M., D. J. Jacob, R. Mathur, and R. V. Martin (2003b), Application of empirical orthogonal functions to evaluate ozone simulations with regional and global models, J. Geophys. Res., 108(D14), 4431, doi:10.1029/2002JD003151

Fishman, J., and J. C. Larsen (1987), Distribution of total ozone and stratospheric ozone in the tropics: Implications for the distribution of tropospheric ozone, J. Geophys. Res., 92, 6627-6634.

Fishman, J., C. E. Watson, J. C. Larsen, and J. A. Logan (1990), Distribution of tropospheric ozone determined from satellite data, J. Geophys. Res., 95(D4), 3599-3617.

Fishman, J., A. E. Wozniak, and J. K. Creilson (2003), Global distribution of tropospheric ozone from satellite measurements using the empirically corrected tropospheric ozone residual technique: Identification of the regional aspects of air pollution, Atmos. Chem. Phys., 3, 893-907.

Fujiwara, M., K. Kita, T. Ogawa, S. Kawakami, T. Sano, N. Komala, S. Saraspriya, and A. Suripto (2000), Seasonal variation of tropospheric ozone in Indonesia revealed by 5 -year ground-based observations, J. Geophys. Res., 105(D2), 1879-1888.

Ginoux, P., M. Chin, I. Tegen, J. M. Prospero, B. Holben, O. Dubovik, and S. Lin (2001), Sources and distributions of dust aerosols simulated with the GOCART model, J. Geophys. Res., 106(D17), 20,225-20,273.

Goldstein, A. H., et al. (2004), Impact of Asian emissions on observations at Trinidad Head, California, during ITCT 2K2, J. Geophys. Res., 109, D23S17, doi:10.1029/2003JD004406.

Hasekamp, O. P., and J. Landgraf (2001), Ozone profile retrieval from backscattered ultraviolet radiances: The inverse problem solved by regularization, J. Geophys. Res., 106(D8), 8077-8088.

Hauglustaine, D. A., G. P. Brasseur, and J. S. Levine (1999), A sensitivity simulation of tropospheric ozone changes due to the 1997 Indonesian fire emissions, Geophys. Res. Lett., 26(21), 3305-3308.

Hoerling, M. P., T. K. Schaack, and A. J. Lenzen (1991), Global objective tropopause analysis, Mon. Weather Rev., 119(8), 1816-1831. 
Hoinka, K. P. (1998), Statistics of the global tropopause pressure, Mon. Weather Rev., 126(10), 3303-3325.

Hoogen, R., V. V. Rozanov, and J. P. Burrows (1999), Ozone profiles from GOME satellite data: Algorithm description and first validation, J. Geophys. Res., 104(D7), 8263-8280.

Hsu, N. C., J. R. Herman, P. K. Bhartia, C. J. Seftor, O. Torres, A. M. Thompson, J. F. Gleason, T. F. Eck, and B. N. Holben (1996), Detection of biomass burning smoke from TOMS measurements, Geophys. Res. Lett., 23(7), 745-748.

Hudman, R. C., et al. (2004), Ozone production in transpacific Asian pollution plumes and implications for ozone air quality in California, J. Geophys. Res., 109, D23S10, doi:10.1029/2004JD004974.

Hudson, R. D., and A. M. Thompson (1998), Tropical tropospheric ozone from Total Ozone Mapping Spectrometer by a modified residual method, J. Geophys. Res., 103(D17), 22,129-22,145.

Jaeglé, L., D. Jaffe, H. U. Price, P. Weiss, P. I. Palmer, M. J. Evans, D. J. Jacob, and I. Bey (2003), Sources and budgets for CO and ozone in the northeastern Pacific during the spring of 2001: results from the PHOBEA-II experiment, J. Geophys. Res., 108(D20), 8802, doi:10.1029/2002JD003121.

Jiang, Y., and Y. L. Yung (1996), Concentrations of tropospheric ozone from 1979 to 1992 over tropical Pacific South America from TOMS data, Science, 272, 714-716

Kim, J. H., and M. J. Newchurch (1996), Climatology and trends of tropospheric ozone over the eastern Pacific Ocean: The influences of biomass burning and tropospheric dynamics, Geophys. Res. Lett., 23(25), $3723-$ 3726.

Kim, J. H., R. D. Hudson, and A. M. Thompson (1996), A new method of deriving time-averaged tropospheric column ozone over the tropics using Total Ozone Mapping Spectrometer (TOMS) radiances: Intercomparison and analysis using TRACE-A data, J. Geophys. Res., 101(D19), 24,31724,330

Kim, J. H., M. J. Newchurch, and K. Han (2001), Distribution of Tropical Tropospheric Ozone determined by the scan-angle method applied to TOMS measurements, J. Atmos. Sci., 58(18), 2699-2708.

Kim, J. H., S. Na, M. J. Newchurch, and R. V. Martin (2005), Tropical tropospheric ozone morphology and seasonality seen in satellite, model, and in situ measurements, J. Geophys. Res., 110, D02303, doi:10.1029/ 2003JD004332.

Kley, D., P. J. Crutzen, H. G. J. Smit, H. Vomel, S. J. Oltmans, H. Grassl, and V. Ramanathan (1996), Observations of near-zero ozone concentrations over the convective Pacific: effects on air chemistry, Science, 274(274), 230-233.

Lal, S., and M. G. Lawrence (2001), Elevated mixing ratios of surface ozone over the Arabian Sea, Geophys. Res. Lett., 28(8), $1487-1490$

Lamarque, J.-F., B. V. Khattatov, and J. C. Gille (2002), Constraining tropospheric ozone column through data assimilation, J. Geophys. Res., 107(D22), 4651, doi:10.1029/2001JD001249.

Law, K. S., et al. (2000), Comparison between global chemistry transport model results and Measurement of Ozone and Water Vapor by Airbus In-Service Aircraft (MOZAIC) data, J. Geophys. Res., 105(D1), $1503-$ 1525 .

Li, Q., et al. (2001), A Tropospheric Ozone Maximum Over the Middle East, Geophys. Res. Lett., 28(17), 3235-3238.

Li, Q. B., D. J. Jacob, T. D. Fairlie, H. Y. Liu, R. M. Yantosca, and R. V. Martin (2002a), Stratospheric versus pollution influences on ozone at Bermuda: Reconciling past analyses, J. Geophys. Res., 107(D22), 4611, doi:10.1029/2002JD002138.

Li, Q. B., et al. (2002b), Transatlantic transport of pollution and its effects on surface ozone in Europe and North America, J. Geophys. Res., 107(D13), 4166, doi:10.1029/2001JD001422.

Li, Q. B., D. J. Jacob, R. M. Yantosca, J. W. Munger, and D. D. Parrish (2004), Export of $\mathrm{NO}_{\mathrm{y}}$ from the North American boundary layer: Reconciling aircraft observations and global model budgets, J. Geophys. Res., 109, D02313, doi:10.1029/2003JD004086.

Liu, H., D. J. Jacob, L. Y. Chan, S. J. Oltmans, I. Bey, R. M. Yantosca, J. M. Harris, B. N. Duncan, and R. V. Martin (2002), Sources of tropospheric ozone along the Asian Pacific Rim: An analysis of ozonesonde observations, J. Geophys. Res., 107(D21), 4573, doi:10.1029/2001JD002005.

Liu, X., K. Chance, C. E. Sioris, R. J. D. Spurr, T. P. Kurosu, R. V. Martin, and M. J. Newchurch (2005), Ozone profile and tropospheric ozone retrievals from Global Ozone Monitoring Experiment: Algorithm description and validation, J. Geophys. Res., 110, D20307, doi:10.1029/ 2005JD006240.

Logan, J. A. (1999), An analysis of ozonesonde data for the troposphere: Recommendations for testing 3-D models and development of a gridded climatology for tropospheric ozone, J. Geophys. Res., 104(D13), $16,115-16,149$
Marenco, A., et al. (1998), Measurement of ozone and water vapor by Airbus in-service aircraft: The MOZAIC airborne program, An overview, J. Geophys. Res., 103(D19), 25,631-25,642.

Martin, R. V., et al. (2002a), Interpretation of TOMS observations of tropical tropospheric ozone with a global model and in situ observations, J. Geophys. Res., 107(D18), 4351, doi:10.1029/2001JD001480.

Martin, R. V., et al. (2002b), An improved retrieval of tropospheric nitrogen dioxide from GOME, J. Geophys. Res., 107(D20), 4437, doi:10.1029/ 2001JD001027.

Martin, R. V., D. J. Jacob, K. Chance, T. P. Kurosu, P. I. Palmer, and M. J. Evans (2003), Global inventory of nitrogen oxide emissions constrained by space-based observations of $\mathrm{NO}_{2}$ columns, J. Geophys. Res., 108(D17), 4537, doi:10.1029/2003JD003453.

McLinden, C. A., S. C. Olsen, B. Hannegan, O. Wild, M. J. Prather, and J. Sundet (2000), Stratospheric ozone in 3-D models: A simple chemistry and the cross-tropopause flux, J. Geophys. Res., 105(D11), $14,653-14,665$.

McPeters, R. D., J. A. Logan, and G. J. Labow (2003), Ozone climatological profiles for version 8 TOMS and SBUV retrievals, Eos. Trans. $A G U, 84(46)$, Fall Meet. Suppl., Abstract A21D-0998.

Moxim, W. J., and H. Levy II (2000), A model analysis of the tropical South Atlantic Ocean tropospheric ozone maximum: The interaction of transport and chemistry, J. Geophys. Res., 105(D13), 17,393-17,415.

Munro, R., R. Siddans, W. J. Reburn, and B. Kerridge (1998), Direct measurement of tropospheric ozone from space, Nature, 392, 168-171.

Myneni, R. B., R. R. Nemani, and S. W. Running (1997), Estimation of Global Leaf Area Index and absorbed \{PAR $\}$ using radiative transfer models, IEEE Trans. Geosci. Remote Sens., 35, 1380-1393.

Newchurch, M. J., X. Liu, and J. H. Kim (2001), Lower Tropospheric Ozone (LTO) derived from TOMS near mountainous regions, J. Geophys. Res., 106(D17), 20,403-20,412.

Newchurch, M. J., D. Sun, J. H. Kim, and X. Liu (2003a), Tropical tropospheric ozone derived using Clear-Cloudy Pairs (CCP) of TOMS measurements, Atmos. Chem. Phys., 3, 683-695.

Newchurch, M. J., M. A. Ayoub, S. Oltmans, B. Johnson, and F. J. Schmidlin (2003b), Vertical distribution of ozone at four sites in the United States, J. Geophys. Res., 108(D1), 4031, doi:10.1029/ 2002JD002059

Oltmans, S. J., et al. (2004), Tropospheric ozone over the North Pacific from ozonesonde observations, J. Geophys. Res., 109, D15S01, doi:10.1029/2003JD003466.

Park, R. J., D. J. Jacob, B. D. Field, R. M. Yantosca, and M. Chin (2004), Natural and transboundary pollution influences on sulfate-nitrate-ammonium aerosols in the United States: Implications for policy, J. Geophys. Res., 109, D15204, doi:10.1029/2003JD004473.

Patterson, E. M., D. A. Gillette, and B. H. Stockton (1977), Complex index of refraction between 300 and $700 \mathrm{~nm}$ for Saharan aerosols, J. Geophys. Res., 82, 3153-3160.

Peters, W., M. C. Krol, J. P. F. Fortuin, H. M. Kelder, A. M. Thompson, C. R. Becker, J. Lelieveld, and P. J. Crutzen (2004), Tropospheric ozone over a tropical Atlantic station in the Northern Hemisphere: Paramaribo, Surinam (6N, 55W), Tellus, 56B, 21-34.

Rodgers, C. D. (2000), Inverse Methods for Atmospheric Sounding: Theory and Practice, World Sci., Hackensack, N. J.

Sauvage, B., V. Thouret, J.-P. Cammas, F. Gheusi, G. Athier, and P. Nedelec (2005), Tropospheric ozone over equatorial Africa: Regional aspects from the MOZAIC data, Atmos. Chem. Phys., 5, 311-335.

Sudo, K., and M. Takahashi (2001), Simulation of tropospheric ozone changes during 1997-1998 El Nino: Meteorological impact on tropospheric photochemistry., Geophys. Res. Lett., 28(21), 4091-4094.

Sun, D. (2003), Tropical tropospheric ozone: New methods, comparisons, and model evaluations of controlling processes, Ph.D. dissertation thesis, Univ. of Ala., Huntsville.

Thompson, A. M., and R. D. Hudson (1999), Tropical tropospheric ozone (TTO) maps from Nimbus 7 and Earth Probe TOMS by the modifiedresidual method: Evaluation with sondes, ENSO signals, and trends from Atlantic regional time series, J. Geophys. Res., 104(D21), 26,96126,975 .

Thompson, A. M., B. G. Doddridge, J. C. Witte, R. D. Hudson, W. T. Luke, J. E. Johnson, B. J. Johnson, S. J. Oltmans, and R. Weller (2000), A tropical Atlantic paradox: Shipboard and satellite views of a tropospheric ozone maximum and wave-one in January-February 1999, Geophys. Res. Lett., 27(20), 3317-3320.

Thompson, A. M., J. C. Witte, R. D. Hudson, H. Guo, J. R. Herman, and M. Fujiwara (2001), Tropical tropospheric ozone and biomass burning, Science, 291, 2128-2132.

Thompson, A. M., et al. (2003), Southern Hemisphere Additional Ozonesondes (SHADOZ) 1998-2000 tropical ozone climatology: 2. Tropospheric variability and the zonal wave-one, J. Geophys. Res., 108(D2), 8241, doi:10.1029/2002JD002241. 
Thouret, V., A. Marenco, J. A. Logan, P. Nedelee, and C. Grouhel (1998), Comparisons of ozone measurements from the MOZAIC airborne program and the ozone sounding network at eight locations, J. Geophys. Res., 103(D19), 25,695-25,720.

Valks, P. J. M., R. B. A. Koelemeijer, M. van Weele, P. van Velthoven, J. P. F. Fortuin, and H. Kelder (2003), Variability in tropical tropospheric ozone: Analysis with Global Ozone Monitoring Experiment observations and a global model, J. Geophys. Res., 108(D11), 4328, doi:10.1029/ 2002JD002894.

van der A, R. J., R. F. van Oss, A. J. M. Piters, J. P. F. Fortuin, Y. J. Meijer, and H. M. Kelder (2002), Ozone profile retrieval from recalibrated GOME data, J. Geophys. Res., 107(D15), 4239, doi:10.1029/ 2001JD000696.

Ziemke, J. R., and S. Chandra (1999), Seasonal and interannual variabilities in tropical tropospheric ozone, J. Geophys. Res., 104(D17), 21,42521,442 .

Ziemke, J. R., S. Chandra, and P. K. Bhartia (1998), Two new methods for deriving tropospheric column ozone from TOMS measurements: Assimilated UARS MLS/HALOE and convective-cloud differential techniques, J. Geophys. Res., 103(D17), 22,115-22,127.
Ziemke, J. R., S. Chandra, and P. K. Bhartia (2001), "Cloud slicing": A new technique to derive upper tropospheric ozone from satellite measurements, J. Geophys. Res., 106(D9), 9853-9867.

K. Chance, T. P. Kurosu, X. Liu, R. V. Martin, C. E. Sioris, and R. J. D. Spurr, Atomic and Molecular Physics Division, Harvard-Smithsonian Center for Astrophysics, Cambridge, MA 02138, USA. (xliu@cfa.harvard. edu)

R. Chatfield, Atmospheric Chemistry and Dynamics Branch, NASA Ames Research Center, Moffett Field, CA 94035-1000, USA.

T. M. Fu, D. J. Jacob, J. A. Logan, and I. A. Megretskaia, Division of Engineering and Applied Sciences, Harvard University, Cambridge, MA 02138, USA.

M. J. Newchurch, Atmospheric Science Department, University of Alabama in Huntsville, Huntsville, AL 35805, USA.

P. I. Palmer, School of Earth and Environment, University of Leeds, Leeds LS2 9JT, UK. 